\title{
The AC4 Protein of a Cassava Geminivirus Is Required for Virus Infection
}

\author{
Kegui Chen, ${ }^{1,2}$ Behnam Khatabi, ${ }^{1,3}$ and Vincent N. Fondong ${ }^{1, \dagger}$ \\ ${ }^{1}$ Delaware State University, Department of Biological Sciences, Dover, Delaware, U.S.A. \\ ${ }^{2}$ Kegui Chen, Institute of Biotechnology and Nuclear Technology, Sichuan Academy of Agricultural Sciences, Chengdu, \\ Sichuan, P.R. China \\ ${ }^{3}$ Department of Natural Sciences, Department of Agriculture, Food and Resource Sciences, Princess Anne, MD 21853, U.S.A. \\ Accepted 28 January 2019.
}

\begin{abstract}
Geminiviruses (family Geminiviridae) are among the most devastating plant viruses worldwide, causing severe damage in crops of economic and subsistence importance. These viruses have very compact genomes and many of the encoded proteins are multifunctional. Here, we investigated the role of the East African cassava mosaic Cameroon virus (EACMCV) AC4 on virus infectivity in Nicotiana benthamiana. Results showed that plants inoculated with EACMCV containing a knockout mutation in an AC4 open reading frame displayed symptoms 2 to 3 days later than plants inoculated with wild-type virus, and these plants recovered from infection, whereas plants inoculated with the wild-type virus did not. Curiously, when an additional mutation was made in the knockout mutant, the resulting double mutant virus completely failed to cause any apparent symptoms. Interestingly, the role of $\mathrm{AC4}$ on virus infectivity appeared to be dependent on an encoded $\mathrm{N}$-myristoylation motif that mediates cell membrane binding. We previously showed that EACMCV containing the AC4 ${ }^{\text {T38I }}$ mutant produced virus progeny characterized by second-site mutations and reversion to wild-type virus. These results were confirmed in this study using additional mutations. Together, these results show involvement of EACMCV AC4 in virus infectivity; they also suggest a role for the combined action of mutation and selection, under prevailing environmental conditions, on begomovirus genetic variation and diversity.
\end{abstract}

Geminiviruses (family Geminiviridae) are among the most devastating plant pathogens worldwide, causing heavy losses on food and cash crops such as cassava, tomatoes, grain legumes, vegetables, maize, and cotton. These viruses therefore represent a threat to global food security and sustainability. During the last two decades, epidemics of newly emerging

${ }^{\dagger}$ Corresponding author: V. N. Fondong; vfondong@desu.edu

Funding: This project was supported by National Science Foundation grant number IOS-1212576. Sequencing and analysis were partially supported through funding from Delaware INBRE (Idea Network of Biomedical Research Excellence) (National Institute of General Medical Sciences [NIGMS] 2P20GM103446), the State of Delaware, and the Delaware Biotechnology Institute.

*The $\boldsymbol{e}$-Xtra logo stands for "electronic extra" and indicates that one supplementary figure and one supplementary table are published online.

The author(s) declare no conflict of interest.

(C) 2019 The American Phytopathological Society geminiviruses have caused huge crop losses and threatened crop production, particularly in the tropics and subtropics. Begomoviruses (genus Begomovirus) have been characterized extensively at the molecular level, due in part to their agricultural importance. These viruses have very compact genomes, which are made up of one (monopartite) or two (bipartite) circular single-stranded DNA (ssDNA) molecules, each ranging in size from 2.6 to $2.8 \mathrm{~kb}$ (Patel et al. 1993). The geminiviral genome is packaged in icosahedral twinned particles, a highresolution structure of which was recently elucidated for African cassava mosaic virus (ACMV), using electron cryomicroscopy (Hipp et al. 2017). Replication of the genome follows a combination of rolling circle (Gutierrez 1999) and recombination-mediated replication (Gutierrez 1999; Jeske et al. 2001) and occurs in the nuclei of infected plant cells, producing double-stranded DNA (dsDNA) replicative form intermediates (Stenger et al. 1991). Because of the very compact nature of geminivirus genomes, encoded genes play multiple functions (Fondong 2013).

The bipartite begomovirus AC4 protein and its monopartite homolog C4 play important roles in virus pathogenicity. In the monopartite begomoviruses, disruption of $\mathrm{C} 4$ reduces symptom development in many begomovirus infections ( $\mathrm{Li}$ et al. 2018; Stanley and Latham 1992; Teng et al. 2010). Moreover, the C4 proteins of several monopartite begomoviruses, including beet curly top virus and beet severe curly top virus (BSCTV) have been observed to alter cell division progression in Arabidopsis thaliana and Nicotiana benthamiana (Latham et al. 1997; Mills-Lujan and Deom 2010; Piroux et al. 2007), implying that the leaf-curling and vein-swelling symptoms observed in plants expressing the $\mathrm{C} 4$ protein are caused by an abnormal cell cycle. Indeed, BSCTV C4 has been shown to regulate the cell cycle by inducing expression of RKP, which is a cell-cycle regulator (Lai et al. 2009). Furthermore, several C4 proteins have been shown to induce plant developmental abnormalities by relocating shaggy-like protein kinases $(\mathrm{SK} \eta)$ from the nucleus to the plasma membrane, thereby affecting the brassinosteroid (BR) signaling pathways (Bi et al. 2017; Dogra et al. 2009; MillsLujan and Deom 2010; Mills-Lujan et al. 2015; Mei et al. 2018a and b; Piroux et al. 2007). C4 interaction with SK $\eta$ and relocation of the $\mathrm{C} 4-\mathrm{SK} \eta$ complex to the plasma membrane was found to be dependent on $\mathrm{C} 4 \mathrm{~N}$-myristoylation, a process that is dependent on SK $\eta$ phosphorylation of C4 (Mei et al. 2018a and $\mathrm{b}$ ). Also, the $\mathrm{C} 4$ proteins of several monopartite begomoviruses have been shown to suppress posttranscriptional gene silencing (PTGS) (Fondong 2013; Ramesh et al. 2017).

In contrast to $\mathrm{C} 4$, several reports have suggested that the AC4 protein of a number of bipartite begomoviruses play no role in 
virus infectivity (Elmer et al. 1988; Etessami et al. 1991; Hong and Stanley 1995; Hoogstraten et al. 1996; Pooma and Petty 1996; Sung and Coutts 1995). However, recently, Hipp et al. (2016) showed that an AC4 knockout mutant of ACMV from Nigeria abolished virus infectivity, suggesting that this protein is required in virus infection. This has been supported by evidence that the AC4 proteins of East African cassava mosaic Cameroon virus (EACMCV), ACMV and Sri Lankan cassava mosaic virus suppress PTGS activity (Chellappan et al. 2005; Fondong et al. 2007; Vanitharani et al. 2004). Accordingly, Mungbean yellow mosaic virus AC4 was shown to bind to plasma membrane via $S$-palmitoylation and to interact with the receptor-like kinase BARLEY ANY MERISTEM 1 (BAM1) to regulate the cell-to-cell spread of RNA silencing signal (Carluccio et al. 2018). Some of these differences may, at least partially, be explained by the fact that $\mathrm{AC} 4$ and $\mathrm{C} 4$ are the most diverse among geminivirus proteins.

We previously described a point mutation in the EACMCV $\mathrm{AC} 4$ open reading frame (ORF) that reverted to wild type and caused second-site mutations, presumably to facilitate maintenance of genome structure and function (Fondong and Chen 2011). Here, to determine a role for EACMCV AC4, we produced an AC4 knockout mutant and also mutated several additional amino-acid residues that are conserved across most C4/AC4 proteins of monopartite and bipartite begomoviruses. The infectivity of these EACMCV mutants was assessed in $N$. benthamiana and the progeny virus genomes were deep sequenced to determine second-site mutations in the A and B components of the virus. Results from the study show that EACMCV AC4 is involved in virus infectivity and symptom severity. The results also show that some of the mutations caused additional point mutations elsewhere in the viral genome, suggesting that some $\mathrm{AC} 4$ nucleotide residues play a role in virus genomic stability. Implications of these findings with regards to the geminivirus genetic variability and evolution are discussed.

\section{RESULTS}

\section{Infectivity of EACMCV AC4 mutant viruses.}

To investigate the role of EACMCV AC4 in one or both virus infectivity and genome stability, we introduced point mutations of amino-acid residues that are either conserved across $\mathrm{AC} 4$ or $\mathrm{C} 4$ proteins, have been shown to be important for EACMCV AC4 function, or both (Table 1). To knock out the gene, the start codon was changed to ACG $\left(\mathrm{AC}^{\mathrm{M} 1 \mathrm{~T}}\right)$ and, because the seventh codon is a methionine and a potential start codon, codon nine, TCA, was changed to a stop codon to obtain AC4 ${ }^{\text {TAA9 }}$. We previously showed that EACMCV AC4 encodes a consensus $\mathrm{N}$-terminal $\mathrm{N}$-myristoylation motif that influences AC4 biological functions (Fondong et al. 2007) and, based on evidence that mutations in EACMCV AC4 led to second-site mutations and reversions in the AC1 ORF (Fondong and Chen 2011), we carried out additional mutations in the $N$ myristoylation motif and along the ORF, as detailed in Table 1. Except for $\mathrm{AC} 4^{\mathrm{C} 3 \mathrm{~A}}, \mathrm{AC} 4^{\mathrm{G} 2 \mathrm{AC} 3 \mathrm{~A}}$, and $\mathrm{AC} 4^{\mathrm{M} 1 \mathrm{TS} 26 \mathrm{P}}$, there was no change in the amino-acid sequence of the $\mathrm{AC} 1$-encoded protein (Rep). Each clone was coinoculated with the DNA-B component to $N$. benthamiana and symptoms were monitored.

Wild-type symptoms generally started appearing on newly expanded leaves within 7 days of inoculation and, by 10 days postinoculation (dpi), all plants displayed severe leaf curling and stunting. Most of the mutated viral clones caused symptoms that were indistinguishable from symptoms displayed by plants inoculated with wild-type clones. Mutants that caused wildtype symptoms were $\mathrm{AC} 4^{\mathrm{C} 3 \mathrm{~A}}, \mathrm{AC} 4^{\mathrm{S} 6 \mathrm{~F}}, \mathrm{AC} 4^{\mathrm{S} 15 \mathrm{~F}}, \mathrm{AC} 4^{\mathrm{S} 16 \mathrm{~N}}$, $\mathrm{AC} 4^{\mathrm{T} 20 \mathrm{I}}, \mathrm{AC} 4^{\mathrm{S} 48 \mathrm{~L}}, \mathrm{AC} 4^{\mathrm{S} 66 \mathrm{~L}}$, and $\mathrm{AC} 4^{\mathrm{TAA9}}$ (Fig. 1). Plants inoculated with the knockout mutant $\mathrm{AC} 4^{\mathrm{M} 1 \mathrm{~T}}$ and with mutant $\mathrm{AC} 4^{\mathrm{G} 2 \mathrm{~A}}$ showed symptoms 2 to 3 days later than plants inoculated with the wild-type virus, and these plants recovered from infection, while plants inoculated with the wild-type virus continued to display severe symptoms (Fig. 1C, $\mathrm{m}$ and $\mathrm{p}$ ) and eventually died. Remarkably, mutants $\mathrm{AC} 4^{\mathrm{M} 1 \mathrm{TS} 26 \mathrm{P}}$ and $\mathrm{AC} 4^{\mathrm{G} 2 \mathrm{AC} 3 \mathrm{~A}}$ (which each contain an additional mutation to mutants $\mathrm{AC} 4^{\mathrm{M} 1 \mathrm{~T}}$ and $\mathrm{AC} 4^{\mathrm{G} 2 \mathrm{~A}}$, respectively) failed to cause any symptoms (Fig. $1 \mathrm{~A}$, e and $\mathrm{f}$ ). Furthermore, mutants $\mathrm{AC} 4^{\mathrm{T} 38 \mathrm{I}}$ and $\mathrm{AC} 4^{\mathrm{S} 76 \mathrm{~N}}$ caused no apparent symptoms early in infection; however, a proportion of these plants showed symptoms from $21 \mathrm{dpi}$, while others remained symptomless throughout the period of observation (Table 2; Fig. 1).

Southern blot hybridization was used to determine viral DNA accumulation in inoculated plants. Analysis of inoculated leaves from six plants at $5 \mathrm{dpi}$ and newly expanded leaves at 15 dpi showed viral DNA in plants inoculated with the wild-type virus, $\mathrm{AC} 4^{\mathrm{M} 1 \mathrm{~T}}, \mathrm{AC} 4^{\mathrm{G} 2 \mathrm{~A}}$, and $\mathrm{AC} 4^{\mathrm{C} 3 \mathrm{~A}}$. In contrast, no viral DNA was detected at these times in plants inoculated with $\mathrm{AC} 4^{\mathrm{G} 2 \mathrm{AC} 3 \mathrm{~A}}, \mathrm{AC} 4^{\mathrm{M} 1 \mathrm{TS} 26 \mathrm{P}}, \mathrm{AC} 4^{\mathrm{T} 38 \mathrm{I}}$, and $\mathrm{AC} 4^{\mathrm{S} 76 \mathrm{~N}}$ (Fig. 2), consistent with observations on symptom development (Fig. 1).

\section{High-resolution deep sequencing}

of virus progeny of wild type and EACMCV mutants.

Using Sanger sequencing of the intergenic region and an $\mathrm{AC} 1 \mathrm{ORF}$, we previously showed that progeny viruses from the $\mathrm{AC} 4^{\mathrm{T} 38 \mathrm{I}}$ mutant virus contained second-site mutants and that a

Table 1. Codon mutations and amino acids in parenthesis in East African cassava mosaic Cameroon virus AC4 open reading frame and the effect on AC1 codons

\begin{tabular}{|c|c|c|c|c|}
\hline \multirow[b]{2}{*}{ Virus } & \multicolumn{2}{|c|}{ Change in AC4 } & \multicolumn{2}{|c|}{ Change in AC1 } \\
\hline & Wild type & Mutation & Wild type & Mutation \\
\hline$\overline{\mathrm{AC}} 4^{\mathrm{M} 1 \mathrm{~T}}$ & ATG (M) & ACG (T) & GAT (D) & GAC (D) \\
\hline $\mathrm{AC} 4^{\mathrm{G} 2 \mathrm{~A}}$ & GGG (G) & GCG (A) & GGG (G) & GGC (G) \\
\hline $\mathrm{AC} 4^{\mathrm{C} 3 \mathrm{~A}}$ & TGC (C) & GCC (A) & GTG (V) & GGC (G) \\
\hline $\mathrm{AC} 4^{\mathrm{G} 2 \mathrm{AC} 3 \mathrm{~A}}$ & GGG TGC (GC) & GCG GCC (AA) & GGG GTG (GV) & GGC GGC (GG) \\
\hline $\mathrm{AC} 4^{\mathrm{M} 1 \mathrm{TS} 26 \mathrm{P}}$ & $\mathrm{TCA}(\mathrm{S})$ & $\mathrm{CCA}(\mathrm{P})$ & CTC (L) & $\mathrm{CCC}(\mathrm{P})$ \\
\hline $\mathrm{AC} 4^{\mathrm{S} 6 \mathrm{~F}}$ & $\mathrm{TCC}(\mathrm{S})$ & TTC $(\mathrm{F})$ & CTC (L) & CTT (L) \\
\hline AC4 $4^{\text {TAA9 }}$ & TCA (S) & TAA (Stop) & CTC (L) & CTA (L) \\
\hline $\mathrm{AC} 44^{\mathrm{S} 15 \mathrm{~N}}$ & AGT (S) & $\operatorname{AAT}(\mathrm{N})$ & AAG $(\mathrm{K})$ & $\mathrm{AAA}(\mathrm{K})$ \\
\hline $\mathrm{AC} 4^{\mathrm{S} 16 \mathrm{~F}}$ & $\mathrm{TCC}(\mathrm{S})$ & TTC (F) & $\mathrm{TTC}(\mathrm{F})$ & $\mathrm{TTT}(\mathrm{F})$ \\
\hline $\mathrm{AC} 4^{\mathrm{T} 20 \mathrm{I}}$ & $\mathrm{ACC}(\mathrm{T})$ & ATC (I) & $\mathrm{AAC}(\mathrm{N})$ & $\mathrm{AAT}(\mathrm{N})$ \\
\hline $\mathrm{AC} 4^{\mathrm{T} 38 \mathrm{I}}$ & $\mathrm{ACA}(\mathrm{T})$ & ATA (I) & $\mathrm{AAC}(\mathrm{N})$ & AAT (N) \\
\hline $\mathrm{AC} 4^{\mathrm{S} 48 \mathrm{~L}}$ & TCA (S) & TTA (L) & GTC (V) & GTT (V) \\
\hline $\mathrm{AC} 4^{\mathrm{T} 51 \mathrm{I}}$ & ACA (T) & ATA (I) & TAC (Y) & TAT (Y) \\
\hline $\mathrm{AC} 4^{\mathrm{S} 66 \mathrm{~L}}$ & TCG (S) & TTG (L) & GTC (V) & GTT (V) \\
\hline $\mathrm{AC} 4^{\mathrm{S} 76 \mathrm{~N}}$ & $\mathrm{AGC}(\mathrm{S})$ & $\mathrm{AAC}(\mathrm{N})$ & CAG (Q) & CAA (Q) \\
\hline
\end{tabular}


proportion of the progeny viruses reverted to wild type, which then caused wild-type symptoms late in the infection cycle (Fondong and Chen 2011). Here, to further characterize populations of progeny genomes from AC4 mutants, we carried out two progeny virus sequence analysis experiments. First, to capture the full spectrum of mutations in progeny viruses during infection, total plant DNA from samples at 10, 15, and 35 dpi were pooled for plants inoculated with the wild-type

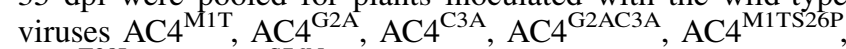
$\mathrm{AC} 4^{\mathrm{T} 38 \mathrm{I}}$, and $\mathrm{AC} 4^{\mathrm{S} 76 \mathrm{~N}}$ and was separated on an agarose gel, followed by excision and isolation of DNA from the band corresponding to replicating viral DNA between 1.5 and $2.0 \mathrm{~kb}$. In the second experiment to analyze viral DNA in lowreplicating viral mutants, especially in symptom and symptomless plants inoculated with $\mathrm{AC} 4^{\mathrm{T} 38 \mathrm{I}}$ and $\mathrm{AC} 4^{\mathrm{S} 76 \mathrm{~N}}$, viral
DNA was amplifyied using rolling circle amplification (RCA) prior to library preparation and sequencing. Here, samples were analyzed at 5 dpi. Because a proportion of plants inoculated with $\mathrm{AC} 4^{\mathrm{T} 38 \mathrm{I}}$ and $\mathrm{AC} 4^{\mathrm{S} 76 \mathrm{~N}}$ were symptomless while others presented symptoms, both categories of samples were analyzed separately at $15 \mathrm{dpi}$.

\section{Analysis of genetic variability caused by EACMCV mutants.}

To determine genetic variability in progeny virus populations, deep-sequencing reads from these experiments were mapped to EACMCV DNA-A and B sequences using the Bowtie2 software package (Langmead and Salzberg 2012), and the resulting SAM files were converted to BAM files using the view command of the SAMtools package (Li et al. 2009).

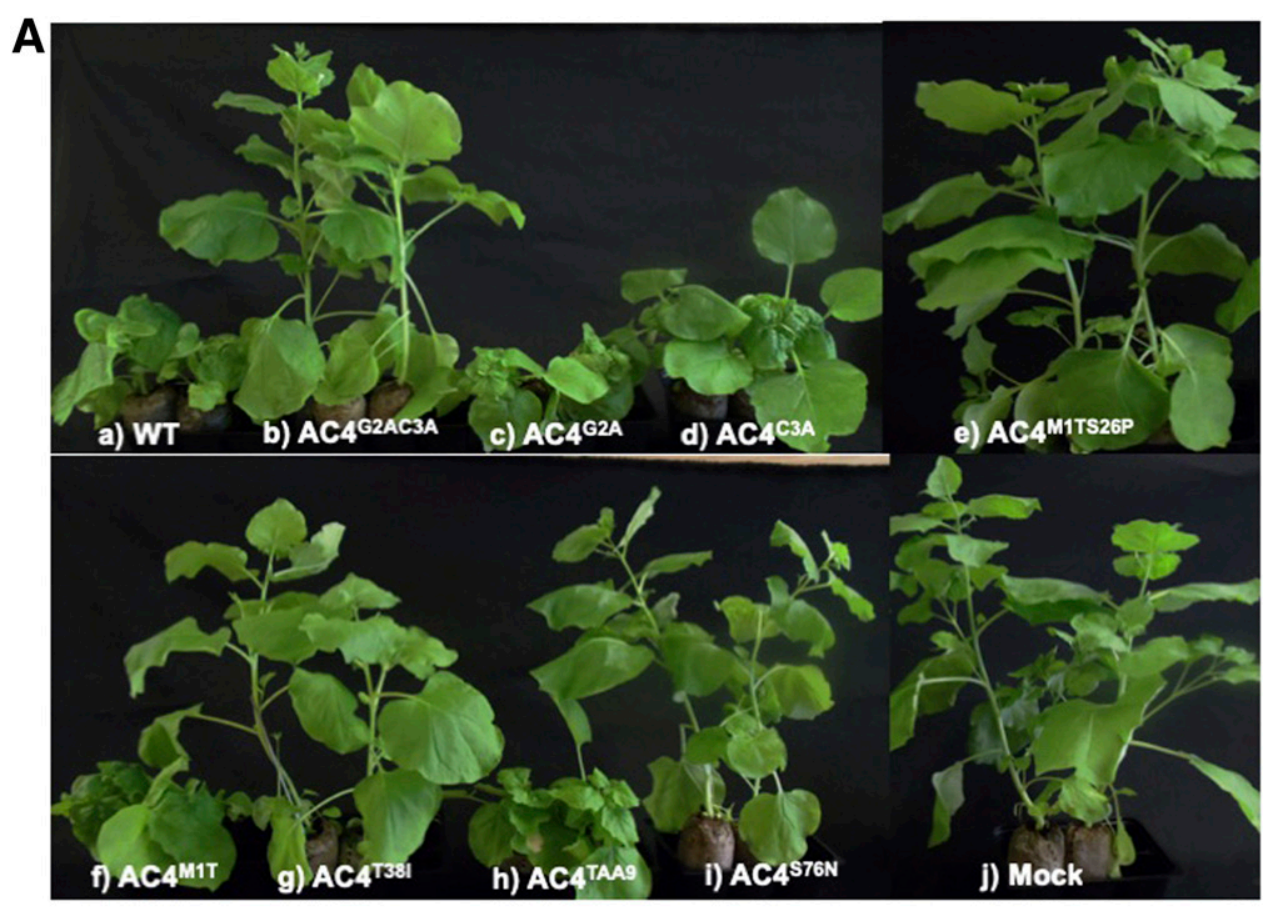

B
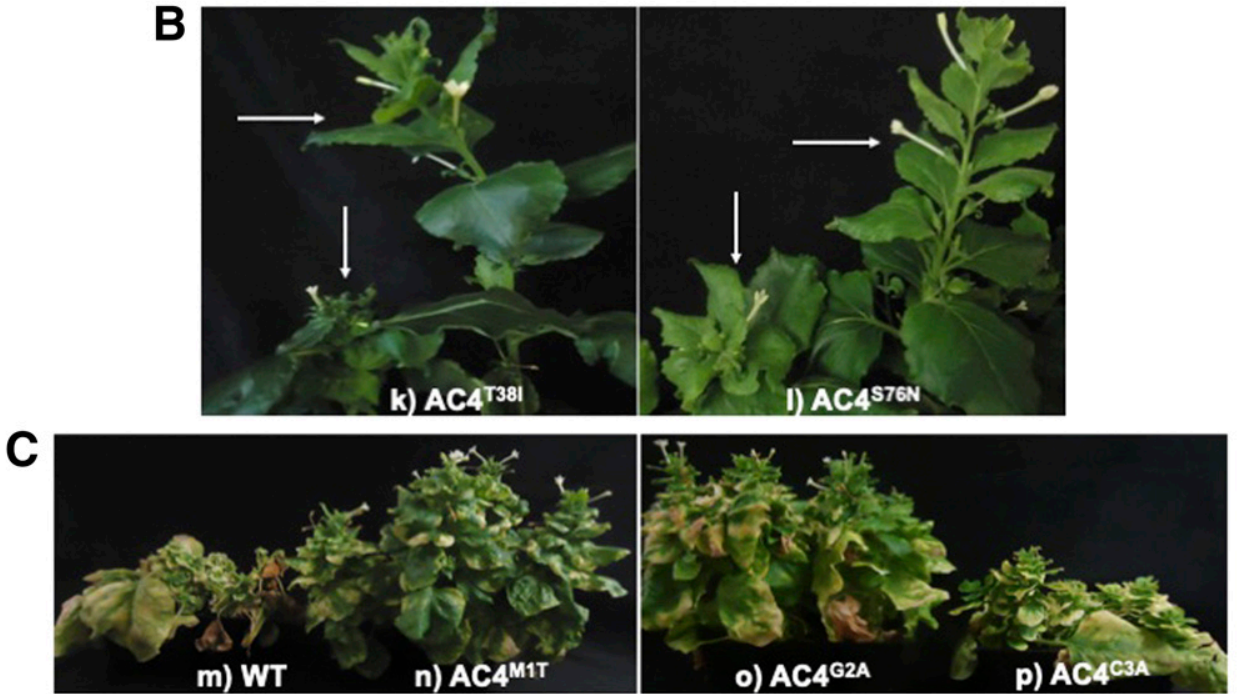

Fig. 1. Infectivity in Nicotiana benthamiana of East African cassava mosaic Cameroon virus and its mutants; wild-type DNA-B was used in all inoculations. A, Plants showing phenotypes at 15 dpi (days postinoculation) with Agrobacterium cultures harboring disarmed Ti binary plasmids with wild-type DNA-A (a), and mutants $\mathrm{AC}^{\mathrm{G} 2 \mathrm{AC} 3 \mathrm{~A}}$ (b), $\mathrm{AC}^{\mathrm{G} 2 \mathrm{~A}}$ (c), $\mathrm{AC} 4^{\mathrm{C} 3 \mathrm{~A}}$ (d), $\mathrm{AC}^{\mathrm{M} 1 \mathrm{TS} 26 \mathrm{P}}$ (e), $\mathrm{AC}^{\mathrm{M} 1 \mathrm{~T}}$ (f), $\mathrm{AC}^{\mathrm{T} 38 \mathrm{I}}$ (g), AC4 ${ }^{\mathrm{TAA} 9}$ (h), AC4 ${ }^{\mathrm{S} 76 \mathrm{~N}}$ (i); and control plants inoculated with Agrobacterium harboring pCambia 2301 (j). B, At 21 dpi, a proportion of plants inoculated with AC4 ${ }^{\mathrm{T} 38 \mathrm{I}}(\mathrm{k})$ and AC4 ${ }^{\mathrm{S} 76 \mathrm{~N}}(\mathrm{l}) \mathrm{displayed}$ late symptoms (vertical arrow) while others (horizontal arrow) remained symptomless. C, From 31 dpi, plants inoculated with wild-type DNA-A (m) and AC4 ${ }^{\text {C3A }}$ (p) exhibited severe symptoms and withered and died at the end of the infection cycle, while plants inoculated with AC4 ${ }^{\mathrm{M} 1 \mathrm{~T}}$ (n) and AC4 ${ }^{\mathrm{G} 2 \mathrm{~A}}$ (o) showed a recovery. 
Single nucleotide polymorphisms (SNPs) were called by SAMtools mpileup variant identification pipeline and were passed through stringent quality control filters. Results of SNPs are shown in Supplementary Table S1 (first four tabs).

Total read number and mapped reads are presented in Table 3. Overall, the number of reads for each virus reflected virus infectivity as indicated by symptom severity in unamplified libraries in experiment 1 (Table $3 \mathrm{~A}$ ). Thus, $\mathrm{AC} 4^{\mathrm{G} 2 \mathrm{AC} 3 \mathrm{~A}}$, $\mathrm{AC} 4{ }^{\mathrm{M} 1 \mathrm{TS} 26 \mathrm{P}}, \mathrm{AC} 4^{\mathrm{T} 38 \mathrm{I}}$, and $\mathrm{AC} 4^{\mathrm{S} 76 \mathrm{~N}}$ recorded the fewest reads in the first experiment in which sequencing libraries were prepared from unamplified viral DNA. Similarly, in the RCAamplified DNA experiment, $\mathrm{AC} 4{ }^{\mathrm{G} 2 \mathrm{AC} 3 \mathrm{~A}}, \mathrm{AC} 4^{\mathrm{M} 1 \mathrm{TS} 26 \mathrm{P}}$, $\mathrm{AC} 4^{\mathrm{T} 38 \mathrm{I}}$, and $\mathrm{AC} 4^{\mathrm{S} 76 \mathrm{~N}}$ recorded low read numbers at $5 \mathrm{dpi}$ and no reads were recorded in systemic leaves of plants inoculated with $\mathrm{AC} 4^{\mathrm{T} 38 \mathrm{I}}$ and $\mathrm{AC} 4^{\mathrm{S} 76 \mathrm{~N}}$ that exhibited no symptoms at 15 dpi (Table 3B).

\section{DNA-level sequence variation.}

The coverage (i.e., number of hits obtained for a given nucleotide position) was analyzed using SAMtools depth command ( $\mathrm{Li}$ et al. 2009) and results are presented in Supplementary Figure S1. As expected, highly infectious mutants and the wild type tended to show higher levels of coverage. Coverage for DNA-B of most of the samples tended to be uniform and displayed comparatively higher coverage than DNA-A coverage, except in low-replicating mutant viruses. The drop in coverage observed at the ends of the genome (common region) is likely due to the low GC content in this region, which is AT rich (Bronstein et al. 2018).

Sequence comparisons of unamplified libraries showed that, for both DNA-A and DNA-B, the wild-type virus progeny had only one substitution while the number of substitutions in mutants ranged from three in $\mathrm{AC} 4^{\mathrm{M} 1 \mathrm{~T}}$ to 54 in $\mathrm{AC} 4^{\mathrm{S} 76 \mathrm{~N}}$ and 70 in $\mathrm{AC} 4^{\mathrm{T} 38 \mathrm{I}}$ (Table $4 \mathrm{~A}$ ). Of these numbers, fewer substitutions were recorded in the $\mathrm{B}$ component and, except for $\mathrm{AC} 4^{\mathrm{S} 76 \mathrm{~N}}$, which had 14 substitutions and $\mathrm{AC} 4^{\mathrm{T} 38 \mathrm{I}}$ with 29 , no substitutions were recorded in the DNA-B component of other mutant or the wild-type virus. In contrast to results recorded in unamplified libraries, few substitutions were recorded in libraries amplified using RCA, in which the number ranged from 0 , in several samples analyzed at $5 \mathrm{dpi}$, to 12 , in $\mathrm{AC}^{\mathrm{S} 76 \mathrm{~N}}$ at $15 \mathrm{dpi}$ (Table $4 \mathrm{~B}$ ). A comparison of $\mathrm{AC} 4^{\mathrm{S} 76 \mathrm{~N}}$ and $\mathrm{AC} 4^{\mathrm{T} 38 \mathrm{I}}$ at $5 \mathrm{dpi}$ and at $15 \mathrm{dpi}$ showed that $\mathrm{AC} 4^{\mathrm{T} 38 \mathrm{I}}$ tended to revert to wild type faster than $\mathrm{AC} 4^{\mathrm{S} 76 \mathrm{~N}}$ and

Table 2. Infectivity of East African cassava mosaic Cameroon virus wild type and mutants in Nicotiana benthamiana obtained from three independent experiments

\begin{tabular}{|c|c|c|c|c|}
\hline Virus & 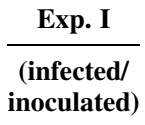 & 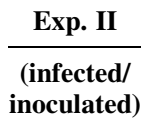 & 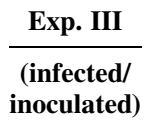 & $\begin{array}{c}\text { Infectivity } \\
(\%)\end{array}$ \\
\hline Wild-type & $6 / 6$ & $8 / 8$ & $10 / 10$ & 100 \\
\hline $\mathrm{AC} 4^{\mathrm{MiT}}$ & $0 / 6$ & $0 / 8$ & $0 / 11$ & 0 \\
\hline $\mathrm{AC} 4^{\mathrm{G} 2 \mathrm{~A}}$ & $6 / 6$ & $9 / 9$ & $10 / 10$ & 100 \\
\hline $\mathrm{AC} 4^{\mathrm{C} 3 \mathrm{~A}}$ & $6 / 6$ & $9 / 9$ & $10 / 10$ & 100 \\
\hline $\mathrm{AC} 4^{\mathrm{S} 6 \mathrm{~F}}$ & $6 / 6$ & $9 / 9$ & $10 / 10$ & 100 \\
\hline $\mathrm{AC} 4^{\text {TAA9 }}$ & $6 / 6$ & $9 / 9$ & $10 / 10$ & 100 \\
\hline $\mathrm{AC} 4^{\mathrm{G} 2 \mathrm{AC} 3 \mathrm{~A}}$ & $0 / 6$ & $0 / 8$ & $0 / 11$ & 0 \\
\hline $\mathrm{AC} 4^{\mathrm{M} 1 \mathrm{TS} 26 \mathrm{P}}$ & $0 / 5$ & $0 / 7$ & $0 / 10$ & 0 \\
\hline $\mathrm{AC} 4^{\mathrm{T} 38 \mathrm{I}}$ & $1 / 6$ & $3 / 9$ & $3 / 10$ & 28 \\
\hline $\mathrm{AC} 4^{\mathrm{S} 76 \mathrm{~N}}$ & $1 / 6$ & $2 / 9$ & $2 / 10$ & 20 \\
\hline $\mathrm{AC} 4^{\mathrm{S} 48 \mathrm{~L}}$ & $6 / 6$ & $9 / 9$ & $5 / 5$ & 100 \\
\hline $\mathrm{AC} 4^{\mathrm{T} 51 \mathrm{I}}$ & $6 / 6$ & $9 / 9$ & $5 / 5$ & 100 \\
\hline $\mathrm{AC} 4^{\mathrm{S} 66 \mathrm{~L}}$ & $6 / 6$ & $9 / 9$ & $5 / 5$ & 100 \\
\hline $\mathrm{AC} 4{ }^{\mathrm{S} 15 \mathrm{~N}}$ & $6 / 6$ & $9 / 9$ & $5 / 5$ & 100 \\
\hline $\mathrm{AC} 4^{\mathrm{S} 16 \mathrm{~F}}$ & $6 / 6$ & $9 / 9$ & $5 / 5$ & 100 \\
\hline $\mathrm{AC} 4^{\mathrm{T} 20 \mathrm{I}}$ & $6 / 6$ & $9 / 9$ & $5 / 5$ & 100 \\
\hline
\end{tabular}

this resulted in a systemic spread of the variants with only three substitutions, as compared with the 12 for $\mathrm{AC} 4^{\mathrm{S} 76 \mathrm{~N}}$. Mutation maps showing substitutions recorded in this study indicate a uniform distribution for the unamplified library, while substitutions in the amplified libraries are between 2,200 and 2,800 bp of DNA-A component (Fig. 3).

We classified substitutions into transitions (interchange of purine or of pyrimidine bases) or transversions (interchange of purine and pyrimidine bases). In the unamplified library experiment, a total of 91 transversions and 44 transitions (a ratio of 2:1) were recorded; a similar proportion was recorded in the amplified library, where 26 transversions and 14 transitions were recorded. Thus, because, there are two possible transversions compared with one possible transition, the rates of transitions and transversions were similar (Table 4). As for GC content of progeny viruses, there were 10 more $A / T \rightarrow G / C$ substitutions than $\mathrm{G} / \mathrm{C} \rightarrow \mathrm{A} / \mathrm{T}$ substitutions in both unamplified (63:43) and amplified (24:14) library experiments (Table 4), thus progeny viruses exhibited a higher GC content than the parent virus.

\section{Amino-acid changes.}

Because of the very compact nature of geminivirus genomes, genes play multiple functions (Fondong 2013). Thus, it is expected that there will be a strong selection pressure for function and to maintain gene sequence fidelity. Indeed, except for one amino-acid substitution in AC4 protein, $\mathrm{P} 21 \rightarrow \mathrm{H}$ $\left(\mathrm{AC} 4^{\mathrm{T} 38 \mathrm{I}}\right)$ and $\mathrm{P} 21 \rightarrow \mathrm{Q}\left(\mathrm{AC} 4^{\mathrm{S} 76 \mathrm{~N}}\right)$ (Table 5; Fig. 4), all substitutions were conserved in all proteins, consistent with functional conservation and maintenance of viral proteins. Of all the mutant viruses analyzed, only $\mathrm{AC} 4{ }^{\mathrm{M} 1 \mathrm{~T}}$ recorded no amino-acid change.

A deeper analysis of the encoded proteins showed important observations. For example, in the Rep (encoded by AC1 ORF),

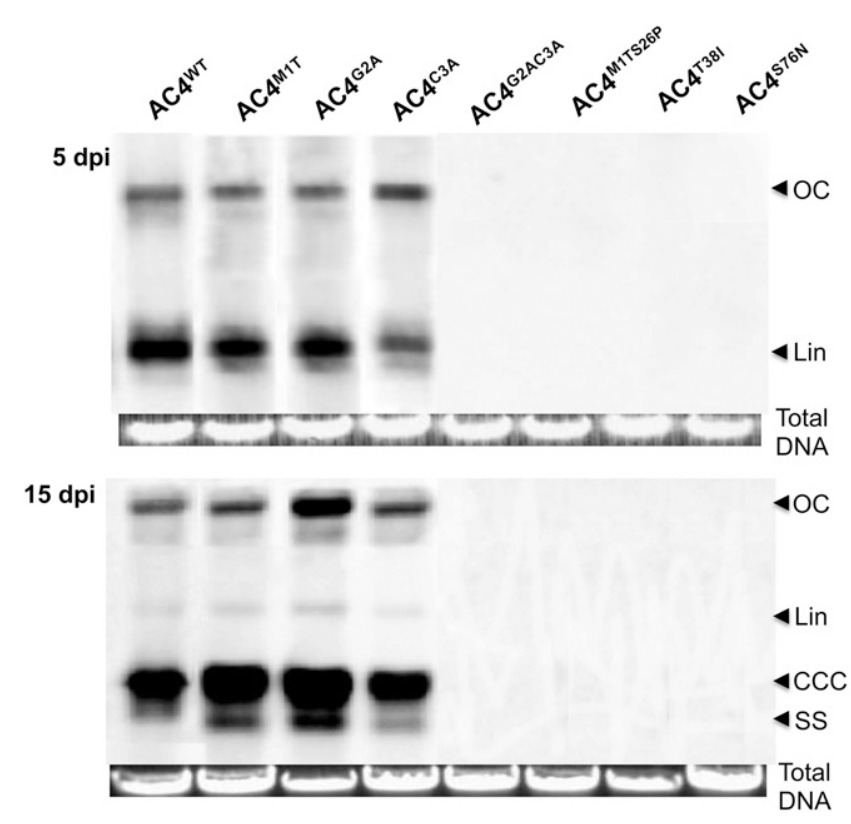

Fig. 2. Southern blot determination of viral DNA accumulation in plants infected with East African cassava mosaic Cameroon virus (EACMCV) mutants. Nicotiana benthamiana plants were inoculated with clones of EACMCV DNA containing AC4 mutations together with the DNA-B component. Leaf samples were collected from inoculated leaves at 5 days postinoculation (dpi) and newly expanded leaves at $15 \mathrm{dpi}$ from plants inoculated with wild type and mutants $\mathrm{AC} 4^{\mathrm{M} 1 \mathrm{~T}}, \mathrm{AC} 4^{\mathrm{G} 2 \mathrm{~A}}, \mathrm{AC} 4^{\mathrm{C} 3 \mathrm{~A}}, \mathrm{AC} 4^{\mathrm{G} 2 \mathrm{AC} 3 \mathrm{~A}}$, $\mathrm{AC} 4^{\mathrm{T} 38 \mathrm{I}}$, and $\mathrm{AC} 4^{\mathrm{S} 76 \mathrm{~N}}$. Forms of viral DNA: $\mathrm{CCC}=$ covalently closed circular, Lin = linear, OC = open circular, and SS = single stranded. 
there was only one instance where an amino-acid substitution $($ V55 $\rightarrow$ G) (Fig. 4) resulted from GTG $\rightarrow$ GGC double nucleotide substitution. Also, in the unamplified libraries, the V100 $\rightarrow$ A substitution in Rep was recorded in $\mathrm{AC} 4^{\mathrm{G} 2 \mathrm{~A}}, \mathrm{AC} 4^{\mathrm{C} 3 \mathrm{~A}}, \mathrm{AC} 4^{\mathrm{G} 2 \mathrm{AC} 3 \mathrm{~A}}$, and $\mathrm{AC} 4{ }^{\mathrm{T} 38 \mathrm{I}}$, due to $\mathrm{GTC} \rightarrow \mathrm{GCC}$ substitution. As for TrAP and REn, amino-acid substitutions were recorded only in $\mathrm{AC}^{\mathrm{T} 38 \mathrm{I}}$ and $\mathrm{AC} 4^{\mathrm{S} 76 \mathrm{~N}}$ in the unamplified library experiment. Some mutants reverted to wild type in $\mathrm{AC} 4^{\mathrm{M} 1 \mathrm{~T}}, \mathrm{AC} 4^{\mathrm{G} 2 \mathrm{AC} 3 \mathrm{~A}}, \mathrm{AC}^{\mathrm{T} 38 \mathrm{I}}$, and $\mathrm{AC4}^{\mathrm{S} 76 \mathrm{~N}}$ in the unamplified library experiment and $\mathrm{AC4} 4^{\mathrm{C} 3 \mathrm{~A}}$, $\mathrm{AC} 4^{\mathrm{G} 2 \mathrm{AC} 3 \mathrm{~A}}$, and $\mathrm{AC}^{\mathrm{T} 38 \mathrm{I}}$ (at $15 \mathrm{dpi}$ ) in the amplified library experiment. Interestingly, the $\mathrm{S} 76 \rightarrow \mathrm{N}$ mutation was maintained in the amplified library experiment both in the inoculated leaves and in systemic leaves of plants inoculated with $\mathrm{AC} 4{ }^{\mathrm{S} 76 \mathrm{~N}}$. CP showed only one mutation $(\mathrm{V} 32 \rightarrow \mathrm{G})$ in $\mathrm{AC} 4^{\mathrm{T} 38 \mathrm{I}}$ for the unamplified library experiment, while the amplified library experiment recorded six substitutions, one in $\mathrm{AC} 4^{\mathrm{G} 2 \mathrm{AC} 3 \mathrm{~A}}$ and five in $\mathrm{AC} 4^{\mathrm{S} 76 \mathrm{~N}}$ at $15 \mathrm{dpi}$.

In AV2, amino-acid changes were observed only in three mutant viruses, $\mathrm{AC} 4^{\mathrm{G} 2 \mathrm{~A}}$ and $\mathrm{AC} 4^{\mathrm{G} 2 \mathrm{AC} 3 \mathrm{~A}}(\mathrm{Y} 61 \rightarrow \mathrm{H})$ and $\mathrm{AC} 4^{\mathrm{T} 38 \mathrm{I}}$, which in the unamplified library experiment showed a TGA ( stop codon) $\rightarrow$ GGA substitution, resulting in the addition of six amino acids to the AV2 sequence (Fig. 4). No amino-acid changes were recorded in $\mathrm{BV} 1$ and $\mathrm{BC} 1$, which each recorded two nucleotide substitutions in the unamplified experiment. Together, these data show that, in most amino-acid changes, the number of nucleotide changes required to cause a codon change was the driving force, as amino-acid changes requiring a single nucleotide change predominated, compared with changes requiring two nucleotide changes.

\section{DISCUSSION}

There have been conflicting reports on the role of the geminivirus AC4 (or its $\mathrm{C} 4$ homolog) in virus infectivity. For example, it was suggested not to play a role in infectivity of several bipartite begomoviruses (Elmer et al. 1988; Etessami et al. 1991; Hoogstraten et al. 1996; Pooma and Petty 1996; Sung and Coutts 1995) even though Hipp et al. (2016) recently showed that an AC4 knockout mutant of ACMV from Nigeria abolished virus infectivity, suggesting that this protein is required in virus infection. Monopartite begomovirus C4 protein has been found to be involved in the pathogenicity of several viruses (Jupin et al. 1994; Rigden et al. 1994; Stanley and Latham 1992; Stanley et al. 1986). The fact that AC4 is contained within the $\mathrm{AC} 1 \mathrm{ORF}$ has complicated in-depth functional analyses without affecting $A C 1$, which codes for Rep, the only viral protein that is indispensable for virus replication (Elmer et al. 1988; Etessami et al. 1991; Haley et al. 1992; Hong and Stanley 1995; Saunders et al. 1991). Additionally, mutations in AC4 have been shown either to revert to wild type, to cause second-site mutations elsewhere in the genome, or both (Fondong and Chen 2011). The fact that early studies did not carry out in-depth analyses of virus progeny populations, for example using deep-sequencing, suggests that some of these phenomena could have affected the results recorded.

In this study, we were able to produce an AC4 knockout mutant, $\mathrm{AC} 4^{\mathrm{MlT}}$, in which the Rep did not contain amino-acid changes. In addition, $\mathrm{AC} 4{ }^{\mathrm{M} 1 \mathrm{~T}}$ did not cause second-site mutations elsewhere in the genome, providing an opportunity for the determination of the role of AC4 in EACMCV infectivity. Thus, the fact that plants inoculated with $\mathrm{AC} 4{ }^{\mathrm{M} 1 \mathrm{~T}}$ displayed symptoms followed by a recovery from infection, whereas the wild-type virus caused plant death, indicates that AC4 plays a role in EACMCV infectivity in $N$. benthamiana. Interestingly, plants inoculated with $\mathrm{AC} 4^{\mathrm{M} 1 \mathrm{TS} 26 \mathrm{P}}$ (in which the conserved serine 26 was changed to proline in the AC4 ${ }^{\mathrm{M} 1 \mathrm{~T}}$ knockout mutant) remained asymptomatic throughout. This suggests that the mild symptoms observed in plants inoculated with $\mathrm{AC} 4^{\mathrm{M} 1 \mathrm{~T}}$, which is likely a leaky mutant, and that the second S26P mutation completely knocked out AC4 function. These results, therefore, agree with recent evidence that ACMV AC4 is required for virus infection (Hipp et al. 2016). Although other mutations, such as AC4 $4^{\mathrm{TAA} 9}$ in which the ninth codon (TCA, serine) was replaced with TAA, a stop codon, caused wild-type symptoms, a Sanger sequencing analysis of

Table 3. Deep sequencing of progeny genomes from wild-type East African cassava mosaic Cameroon virus (EACMCV) and its mutants ${ }^{\mathrm{a}}$

\begin{tabular}{|c|c|c|c|c|c|}
\hline Virus & Total reads & Reads mapped to DNA-A & \% mapped to DNA-A & Reads mapped to DNA-B & \% mapped to DNA-B \\
\hline$\overline{\mathrm{AC} 4} 4^{\mathrm{M} 1 \mathrm{~T}}$ & $4,021,611$ & 10,724 & 0.27 & 245,482 & 6.10 \\
\hline $\mathrm{AC} 4^{\mathrm{G} 2 \mathrm{~A}}$ & $3,290,393$ & 42,445 & 1.29 & 436,256 & 13.26 \\
\hline $\mathrm{AC} 4^{\mathrm{C} 3 \mathrm{~A}}$ & $6,585,217$ & 36,552 & 0.56 & 956,953 & 14.53 \\
\hline $\mathrm{AC} 4^{\mathrm{G} 2 \mathrm{AC} 3 \mathrm{~A}}$ & $5,869,119$ & 15,469 & 0.26 & 340,613 & 5.80 \\
\hline $\mathrm{AC} 4^{\mathrm{M} 1 \mathrm{TS} 26 \mathrm{P}}$ & $2,926,503$ & 8,812 & 0.30 & 87,241 & 2.98 \\
\hline $\mathrm{AC} 4^{\mathrm{S} 76 \mathrm{~N}}$ & $5,804,939$ & 1.703 & 0.03 & 11,382 & 0.20 \\
\hline $\mathrm{AC} 4^{\mathrm{T} 38 \mathrm{I}}$ & $3,599,286$ & 665 & 0.02 & 11,382 & 0.20 \\
\hline WT & $4,319,801$ & 45,449 & 1.05 & 619,013 & 14.33 \\
\hline
\end{tabular}

B, Amplified libraries using rolling circle amplification (RCA) of samples collected at 5 or $15 \mathrm{dpi}$

\begin{tabular}{|c|c|c|c|c|c|c|}
\hline Virus & Dpi & Total reads & Reads mapped to DNA-A & \% Mapped to DNA-A & Reads mapped to DNA-A & \% Mapped to DNA-B \\
\hline$\overline{\mathrm{AC}} 4^{\mathrm{G} 2 \mathrm{~A}}$ & 5 & $1,516,458$ & 71,769 & 4.73 & 331,513 & 22.30 \\
\hline $\mathrm{AC} 4^{\mathrm{C} 3 \mathrm{~A}}$ & 5 & $1,195,315$ & 61,453 & 5.24 & 73,602 & 6.27 \\
\hline $\mathrm{AC} 4^{\mathrm{G} 2 \mathrm{AC} 3 \mathrm{~A}}$ & 5 & $1,405,077$ & 514 & 0.04 & 1,031 & 0.08 \\
\hline $\mathrm{AC} 4^{\mathrm{M} 1 \mathrm{TS} 26 \mathrm{P}}$ & 5 & $1,202,436$ & 1,024 & 0.09 & 470 & 0.04 \\
\hline $\mathrm{AC} 4^{\mathrm{S} 76 \mathrm{~N}}$ & 5 & $1,324,262$ & 5,946 & 0.47 & 379,585 & 29.26 \\
\hline $\mathrm{AC} 4^{\mathrm{T} 38 \mathrm{I}}$ & 5 & $1,349,271$ & 2,866 & 0.22 & 42,605 & 3.29 \\
\hline WT & 5 & $1,000,785$ & 76,575 & 7.65 & 161,159 & 16.43 \\
\hline $\mathrm{AC} 4^{\mathrm{S} 76 \mathrm{~N}} \mathrm{~ns}^{\mathrm{b}}$ & 15 & $1,290,011$ & 0 & 0 & 56 & 0 \\
\hline $\mathrm{AC} 4^{\mathrm{S} 76 \mathrm{~N}_{\mathrm{S}}}$ & 15 & $1,466,631$ & 40,903 & 2.79 & 320,886 & 22.25 \\
\hline $\mathrm{AC} 4^{\mathrm{T} 38 \mathrm{I}} \mathrm{ns}$ & 15 & $1,233,663$ & 27 & 0 & 109 & 0.01 \\
\hline $\mathrm{AC} 4{ }^{\mathrm{T} 38 \mathrm{I}} \mathrm{S}$ & 15 & $1,551,178$ & 17,715 & 1.14 & 172,684 & 11.36 \\
\hline WT & 15 & $1,244,603$ & 219 & 0.02 & 4,262 & 0.35 \\
\hline
\end{tabular}

${ }^{a}$ Numbers of reads recorded from unamplified (A) and from RCA (B) libraries as well as reads that were mapped to the EACMCV DNA-A and DNA-B components and their mapping percentages.

${ }^{\mathrm{b}} \mathrm{ns}=$ no symptoms observed on these plants and $\mathrm{s}=$ plants displayed symptoms. 
$\mathrm{AC} 4{ }^{\mathrm{TAA} 9}$ progeny genomes showed that the G2470T mutation had reverted to wild type, indicating that these symptoms were caused by revertants.

Together, these data suggest that discrepancies in the role of AC4 on begomovirus infectivity could, at least partially, be accounted for by either reversion to wild type, occurrence of second-site mutations elsewhere in the genome, or both. This is because in previous studies (Elmer et al. 1988; Etessami et al. 1991; Hoogstraten et al. 1996; Pooma and Petty 1996; Sung and Coutts 1995), deep sequencing of entire genomes of progeny virus populations was not used to determine whether additional changes resulting from the original mutation in AC4 influenced the observations. Thus, it is possible that, in some of these previous studies, AC4 knockout mutants reverted to wild type or led to second-site mutations, thereby confounding the results.

We also observed that $\mathrm{AC} 4^{\mathrm{G} 2 \mathrm{~A}}$, in which glycine- 2 was substituted with alanine thereby directing AC4 to the chloroplast (Fondong et al. 2007), caused symptoms similar to those caused by $\mathrm{AC} 4^{\mathrm{M} 1 \mathrm{~T}}$. In $\mathrm{AC} 4^{\mathrm{G} 2 \mathrm{~A}}$, the $\mathrm{N}$-myristoylation motif, which mediates AC4 membrane binding, is abolished. This suggests that the role of AC4 in virus infectivity is linked to the $\mathrm{N}$-myristoylation motif-mediated membrane binding. Correspondingly, it was recently shown that the ability of C4 to cause leaf-curling and vein-swelling symptoms was dependent on interaction with $\mathrm{SK} \eta$ and relocation of the $\mathrm{C} 4-\mathrm{SK} \eta$ complex to the plasma membrane, a process that requires $\mathrm{C} 4$
$N$-myristoylation (Mei et al. 2018a and b). Accordingly, $\mathrm{AC} 4^{\mathrm{C} 3 \mathrm{~A}}$, which reduces the efficiency of plasma membrane binding in favor of internal membrane binding (Fondong et al. 2007), is observed not to seriously affect virus infectivity in this study, stressing a link between membrane binding and the role of AC4 in virus infectivity. Indeed, similar to AC4 ${ }^{\text {M1TS26P }}$, plants inoculated with $\mathrm{AC} 4^{\mathrm{G} 2 \mathrm{AC} 3 \mathrm{~A}}$ (which also contains an additional mutation in $\mathrm{AC} 4^{\mathrm{G} 2 \mathrm{~A}}$ ) displayed no symptoms. This indicates that these double mutations completely knockout $\mathrm{AC} 4$, thereby rendering the virus noninfectious. These observations suggest that $\mathrm{C} 4$ and $\mathrm{AC} 4$ are required for virus infection and that this function is dependent on interaction with $\mathrm{SK} \eta$ and relocation of the complex from the nucleus to the membrane, thereby affecting the BR signaling pathways (Mei et al. 2018a and b). This is consistent with results from tobacco mosaic virus (Deng et al. 2016) and cucumber mosaic virus (CMV) (Zhang et al. 2015).

We showed previously that EACMCV exhibits high mutation rates comparable to rates observed in RNA viruses and that it eliminates deleterious mutations (Fondong and Chen 2011). Genetic variation in begomoviruses has been attributed to pseudorecombination, recombination, and acquisition of new DNA components and satellites (Briddon et al. 2010; Rojas and Gilbertson 2008; Seal et al. 2006). The recent emergence of severe begomovirus epidemics especially in cassava, tomato, and cotton, has, at least partly, been attributed to recombination, which presumably results in genomes more

A Experiment 1: Unamplified library

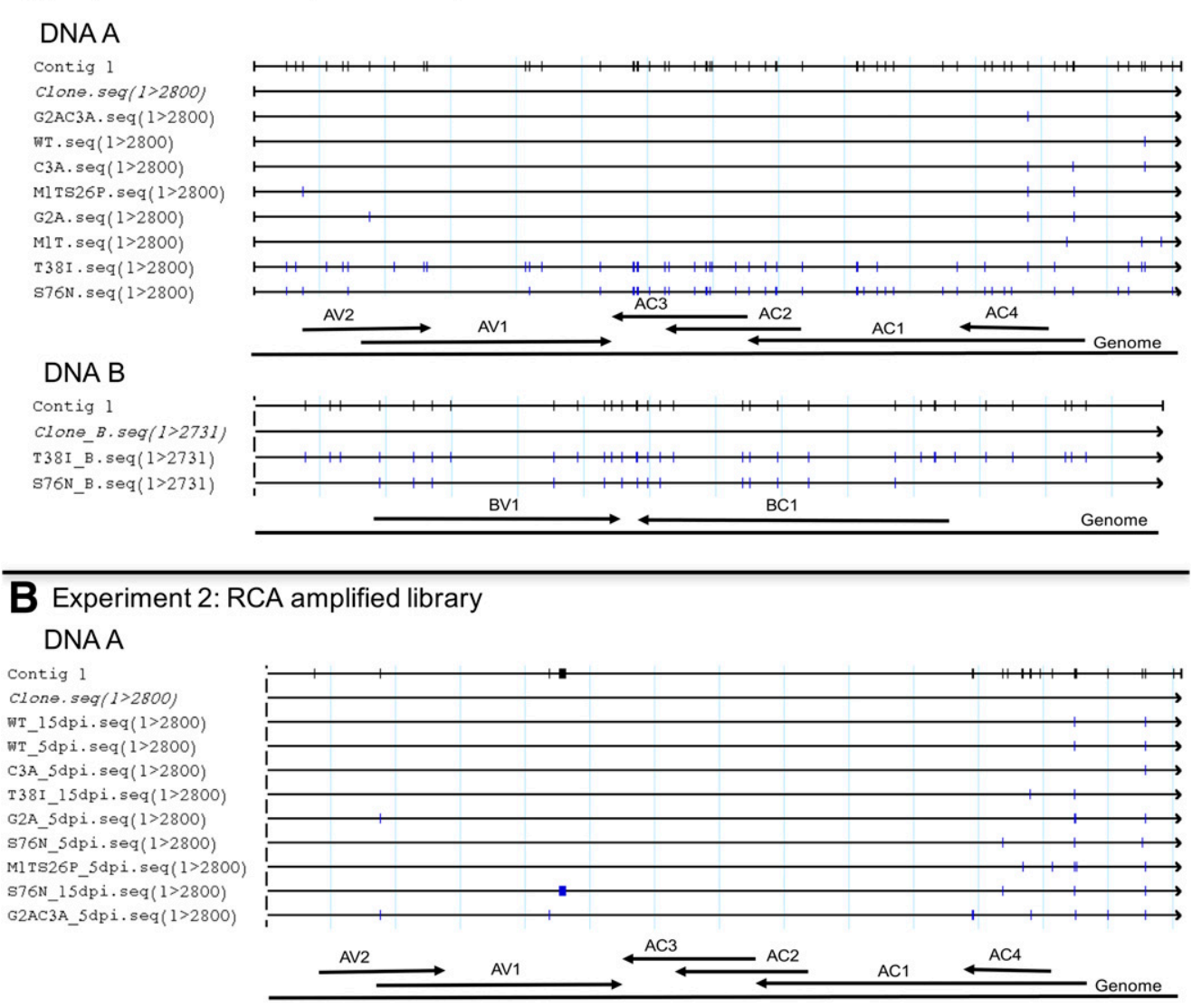

Fig. 3. Genetic variability caused by mutations introduced to East African cassava mosaic Cameroon virus (EACMCV) AC4. Mutants were inoculated to Nicotiana benthamiana, and unamplified and RCA-amplified libraries of progeny viruses were sequenced, using the Illumina HiSeq 2500 platform. A, Progeny virus variants between EACMCV DNA-A and B wild type (WT), $\mathrm{AC} 4^{\mathrm{MlT}}$, AC4 $4^{\mathrm{G} 2 \mathrm{~A}}, \mathrm{AC} 4^{\mathrm{C} 3 \mathrm{~A}}, \mathrm{AC} 4^{\mathrm{G} 2 \mathrm{AC} 3 \mathrm{~A}}, \mathrm{AC}^{\mathrm{M} 1 \mathrm{TS} 26 \mathrm{P}}, \mathrm{AC} 4^{\mathrm{T} 38 \mathrm{I}}$, and $\mathrm{AC} 4^{\mathrm{S} 76 \mathrm{~N}}$ and the EACMCV reference sequence (GenBank DNA-A: AF112354, DNA-B: AF112354) are indicated by vertical lines. The map of EACMCV DNA-A component shows position of substitution (samples were collected at 10 days postinoculation [dpi] and from newly expanded leaves at 15 and 35 dpi). B, EACMCV DNA-A and B WT, AC4 ${ }^{\mathrm{G} 2 \mathrm{~A}}, \mathrm{AC}^{\mathrm{C} 3 \mathrm{~A}}, \mathrm{AC} 4^{\mathrm{G} 2 \mathrm{AC} 3 \mathrm{~A}}, \mathrm{AC} 4^{\mathrm{M} 1 \mathrm{TS} 26 \mathrm{P}}, \mathrm{AC} 4^{\mathrm{T} 38 \mathrm{I}}$, and $\mathrm{AC} 4^{\mathrm{S} 76 \mathrm{~N}}$ and the EACMCV reference sequence $(\mathrm{GenBank}$ AF112354) are indicated by vertical lines (samples at 5 and 15 dpi were extracted from inoculated leaves). 
easily transmitted by the new invasive and polyphagous B biotype of Bemisia tabaci vector (Ahmed et al. 2010; Jiu et al. 2007; Legg and Fauquet 2004; Melgarejo et al. 2013; Pita et al. 2001). The role of single nucleotide misincorporations and the resulting additional genome changes, as observed in this study, have not received adequate attention. Here, results of deep sequencing show that single nucleotide mutations in $\mathrm{AC}^{\mathrm{T} 38 \mathrm{I}}$ $(\mathrm{ACA} \rightarrow \mathrm{ATA})$ and $\mathrm{AC} 4^{\mathrm{S} 76 \mathrm{~N}}(\mathrm{AGC} \rightarrow \mathrm{AAC})$, neither of which resulted in a change in Rep amino-acid sequence, caused multiple second-site mutations elsewhere in the genome. It is therefore possible that single nucleotide mutations, as recorded in this study, together with changes in one or more environmental conditions, vector, or host are at least partially contributing to genome variability and emergence of new begomovirus epidemics.

We note that multiple second-site substitutions observed in $\mathrm{AC} 4^{\mathrm{T} 38 \mathrm{I}}$ and $\mathrm{AC4}{ }^{\mathrm{S} 76 \mathrm{~N}}$ mutant viruses are unlikely to be due to chance events for the following reasons: i) of the 14 mutant viruses investigated in this study, only $\mathrm{AC}^{\mathrm{T} 38 \mathrm{I}}$ and $\mathrm{AC} 4^{\mathrm{S} 76 \mathrm{~N}}$ caused late symptoms in a proportion of plants while other plants remained symptomless; ii) sequenced data showed that progeny genomes in plants with late symptoms had reverted to wild type while genomes in plants that did not display symptoms showed no revertants, thus sequencing data explained phenotypes; iii) moreover, variability was more extensive in inoculated leaves than in systemically infected leaves of symptomatic plants, indicating selection for capable variants; iv) both amplified and unamplified sequencing library approaches used in this study showed that multiple second-site mutations occurred only in $\mathrm{AC} 4^{\mathrm{T} 38 \mathrm{I}}$ and $\mathrm{AC} 4^{\mathrm{S} 76 \mathrm{~N}}$ mutant; v) the wild-type virus used as a control in these experiments did not exhibit multiple substitutions; vi) in this study, variants were detected using a SAMtools mpileup bioinformatics method (Li et al. 2009) that accounts for sequencing error probability and is routinely used to accurately call viral genome SNPs and single nucleotide variants (Batty et al. 2013; Cheleuitte-Nieves et al. 2018; Sobel Leonard et al. 2016; Tweedy et al. 2017; Watson et al. 2015; Willemsen et al. 2016). Taken together, our study shows that $\mathrm{AC}^{\mathrm{T} 38 \mathrm{I}}$ and $\mathrm{AC} 4^{\mathrm{S} 76 \mathrm{~N}}$ mutations cause more variability in virus populations than other mutations investigated and, depending on one or more environmental conditions, vector, or host factors, both mutations are likely to cause virus diversity and evolution.

Table 4. Nucleotide substations and mutation distribution biases in wild-type (WT) East African cassava mosaic Cameroon virus or mutants inoculated in Nicotiana benthamiana

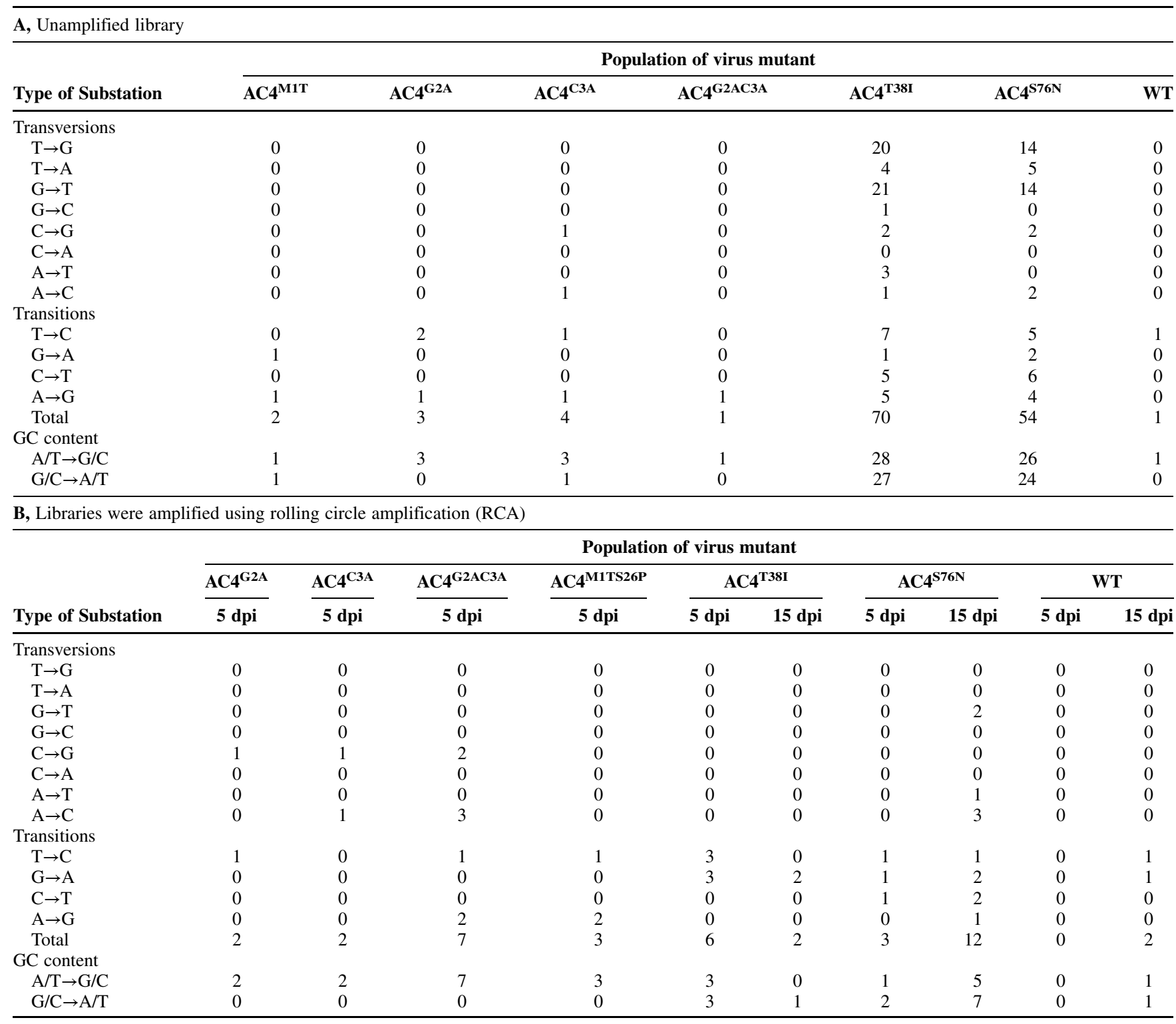


Virus genetic robustness, i.e., the ability of a virus to maintain a relatively constant phenotype despite random mutational input (de Visser et al. 2003; Draghi et al. 2010; Lauring et al. 2013; Masel and Trotter 2010), is a buffering strategy that allows the viral population to increase its genetic diversity through greater exploration of sequence space. Very importantly, genetic robustness allows for the reduction of the number of additional mutations required for virus fitness gain in a new environment (Lauring et al. 2013). It is, therefore, conceivable that the low replicative fidelity exhibited by begomoviruses,

Table 5. Numbers of amino-acid changes recorded in proteins of progeny of East African cassava mosaic Cameroon virus mutants and wild-type virus inoculated to Nicotiana benthamiana

\begin{tabular}{|c|c|c|c|c|c|c|c|c|}
\hline \multicolumn{9}{|c|}{ A, Unamplified library } \\
\hline Virus & $\operatorname{Rep}$ & $\operatorname{Tr} \mathbf{A P}$ & REn & AC4 & $\mathbf{C P}$ & AV2 & BC1 & BV1 \\
\hline$\overline{\mathrm{AC} 4} 4^{\mathrm{M} 1 \mathrm{~T}}$ & 0 & 0 & 0 & - & 0 & 0 & 0 & 0 \\
\hline $\mathrm{AC} 4^{\mathrm{G} 2 \mathrm{~A}}$ & 1 & 0 & 0 & 2 & 0 & 1 & 0 & 0 \\
\hline $\mathrm{AC} 4^{\mathrm{C} 3 \mathrm{~A}}$ & 2 & 0 & 0 & 2 & 0 & 0 & 0 & 0 \\
\hline $\mathrm{AC} 4^{\mathrm{G} 2 \mathrm{AC} 3 \mathrm{~A}}$ & 1 & 0 & 0 & 1 & 0 & 0 & 0 & 0 \\
\hline $\mathrm{AC} 4^{\mathrm{M} 1 \mathrm{TS} 26 \mathrm{P}}$ & 1 & 0 & 0 & 0 & 0 & 0 & 0 & 0 \\
\hline $\mathrm{AC} 4^{\mathrm{T} 38 \mathrm{I}}$ & 1 & 4 & 7 & 2 & 1 & 7 & 2 & 1 \\
\hline $\mathrm{AC} 4^{\mathrm{S} 76 \mathrm{~N}}$ & 2 & 4 & 6 & 4 & 0 & 0 & 2 & 1 \\
\hline Wild type (WT) & 0 & 0 & 0 & 0 & 0 & 0 & 0 & 0 \\
\hline Total & 8 & 8 & 13 & 11 & 1 & 8 & 4 & 2 \\
\hline \multicolumn{9}{|c|}{ B, Libraries were amplified using RCA } \\
\hline Clone & Rep & TrAP & REn & AC4 & $\mathbf{C P}$ & AV2 & BC1 & BV1 \\
\hline $\mathrm{AC} 4^{\mathrm{G} 2 \mathrm{~A}}$ & 0 & 0 & 0 & 1 & 0 & 1 & 0 & $\overline{0}$ \\
\hline $\mathrm{AC} 4^{\mathrm{C} 3 \mathrm{~A}}$ & 1 & 0 & 0 & 0 & 0 & 0 & 0 & 0 \\
\hline $\mathrm{AC} 4^{\mathrm{G} 2 \mathrm{AC} 3 \mathrm{~A}}$ & 0 & 0 & 0 & 2 & 1 & 1 & 0 & 0 \\
\hline $\mathrm{AC} 4^{\mathrm{M} 1 \mathrm{TS} 26 \mathrm{P}}$ & 1 & 0 & 0 & 0 & 0 & 0 & 0 & 0 \\
\hline $\mathrm{AC} 4^{\mathrm{T} 38 \mathrm{I}}-5 \mathrm{dpi}$ & 2 & 0 & 0 & 3 & 0 & 0 & 0 & 0 \\
\hline $\mathrm{AC} 4^{\mathrm{T} 38 \mathrm{I}}-15 \mathrm{dpi}$ & 0 & 0 & 0 & 1 & 0 & 0 & 0 & 0 \\
\hline $\mathrm{AC} 4^{\mathrm{S} 76 \mathrm{~N}}-5 \mathrm{dpi}$ & 0 & 0 & 0 & 1 & 0 & 0 & 0 & 0 \\
\hline $\mathrm{AC} 4^{\mathrm{S} 76 \mathrm{~N}}-15 \mathrm{dpi}$ & 0 & 0 & 0 & 1 & 5 & 0 & 0 & 0 \\
\hline WT-5 & 0 & 0 & 0 & 0 & 0 & 0 & 0 & 0 \\
\hline WT-15 & 0 & 0 & 0 & 0 & 0 & 0 & 0 & 0 \\
\hline Total & 4 & 0 & 0 & 9 & 6 & 2 & 0 & 0 \\
\hline
\end{tabular}

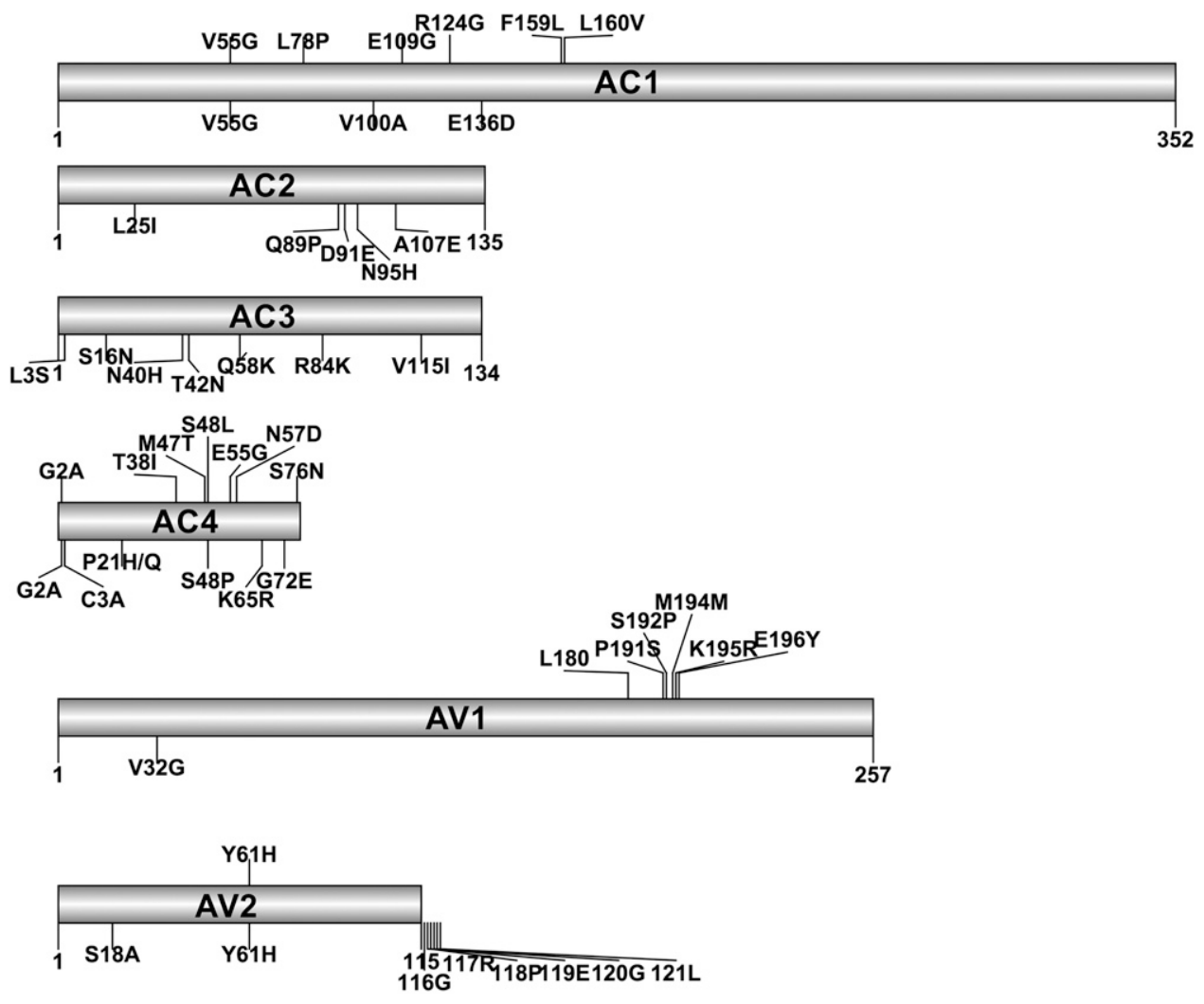

Fig. 4. Amino-acid changes resulting from mutations in East African cassava mosaic Cameroon virus open reading frames (AC1, AC2, AC3, AC4, AV1, AV2) of various mutant viruses tended to occur at specific hotspots. Changes in unamplified DNA libraries are shown in the lower panel while changes in DNA libraries amplified using RCA are in the upper panel. Note that the same mutations frequently occurred in different mutant viruses. 
like in RNA viruses, ensures robustness and the ability of viral populations to produce and maintain mutations that allow quick adaptation to changes in the environment. From our data, it is observed that some nucleotide residues play crucial roles in viral genome stability such that, upon substitution, they cause multiple mutations. Such nucleotide residues, therefore, likely play crucial roles in virus evolution, consistent with evolution being driven by 'safety in numbers' (Elena 2012; Lauring et al. 2013).

Despite the many sources of variation, there is relatively low variation in begomovirus populations. It has been shown in RNA viruses that, in spite of the many sources of variation, there is selection for maintaining a functional encoded protein and nucleic acid structure as well as bottlenecks that eliminate deleterious variants (García-Arenal et al. 2001; Li and Roossinck 2004; Power 2000; Roossinck et al. 1997). We showed previously that, upon infection, $\mathrm{AC}^{\mathrm{T} 38 \mathrm{I}}$ produced diverse populations of EACMCV progeny genomes in inoculated leaves (Fondong and Chen 2011); this diversity then narrowed to only a few point mutations in systemically infected leaves that exhibited typical virus symptoms. Thus, as reported for CMV (Li and Roossinck 2004), selection and systemic spread bottleneck likely limited variation in EACMCV populations in a stochastic manner.

It is important to note that the differences between the RCAamplified and the unamplified DNA libraries could be due, at least in part, to the fact that RCA involves repetitive copying of the same template and therefore specific mutants could have been preferentially amplified and this could underestimate the number of variants in the progeny virus populations compared with unamplified libraries.

\section{MATERIALS AND METHODS}

\section{Construction of plasmids, Agrobacterium transformation, and inoculations.}

The full-length EACMCV DNA-A component (GenBank accession number AF112354) (Fondong et al. 2000) was cloned into the HindIII site of pBluescript II KS (Agilent Technologies, La Jolla, CA, U.S.A.) to obtain pB-EA. To facilitate downstream manipulations, the 1.6-kb BamHI/HindIII fragment of EACMCV DNA-A and an additional BamHI site adjacent to the HindIII site in the vector sequence of pB-EA was polymerase chain reaction (PCR)-amplified using primers (forward and reverse) (5'-TTGGATCCTTTTCTTTGATAATTTG-3' and 5' CCGCTCTAGAACTAGTGGAT-3'). The PCR product was cloned into Gateway recombination plasmid pCR8/GW/ TOPO (Invitrogen Corporation, Carlsbad, CA, U.S.A.), using site-specific recombination as described by the manufacturer. A full-length HindIII EACMCV DNA-A copy was subcloned into the BamHI/HindIII fragment in pCR8/GW/TOPO, thus obtaining a partial tandem repeat of the A component with two virus replication origins. The partial tandem repeat was then cloned into pEarleyGate100 binary vector (Earley et al. 2006) using sitespecific recombination.

To characterize $\mathrm{AC} 4$, mutations were introduced into the AC4 ORF by overlap PCR using the EACMCV 1.6-kb BamHIHindIII fragment in pCR8/GW/TOPO (described above). Specific primers used to introduce mutations are presented in Table 6. Each mutated fragment was PCR-amplified using general primers (forward and reverse) (5'-TTGGATCCTTTTCTTTGATAATTTG-3' and $5^{\prime}$-CCGCTCTAGAACTAGTGGAT-3') and the fragment was cloned into pCR8/GW/TOPO by T/A cloning. These mutations were confirmed by sequencing. To obtain a full-length EACMCV DNA-A containing the AC4 mutations, each mutated fragment was excised from the subclone in pCR8/GW/TOPO, using BamHI, and was used to replace the corresponding fragment in pB-EA, thereby producing a mutated full-length HindIII component A in pBluescript II KS. Mutated full-length HindIII copies were then cloned into the mutated subclone in $\mathrm{pCR} 8 / \mathrm{GW} / \mathrm{TOPO}$ to produce partial tandem repeats with each mutated full-length and subclone containing the same mutation in the two AC4 ORFs (Table 6). These tandem repeats were then transferred into pEarleyGate100 binary vector by recombination. Individual EACMCV DNA-A mutants as well as the EACMCV B component partial repeat described previously (Fondong and Chen 2011) were transformed into Agrobacterium tumefaciens (strain $\mathrm{C1C58}$ ) using the freeze-thaw method. Agrobacterium inoculum preparation and inoculations were as described (Fondong and Chen 2011). Infiltrated plants were placed in a growth room with a 16-h photoperiod and a day temperature of $22^{\circ} \mathrm{C}$ and a night temperature of $18^{\circ} \mathrm{C}$; plants were then monitored for symptom development.

\section{DNA extraction and Southern blot hybridization.}

Total DNA was extracted from inoculated and newly expanded leaves of $N$. benthamiana plants using the CTAB method (Doyle and Doyle 1987). Gel electrophoresis of $15 \mu \mathrm{g}$ of total plant DNA and Southern blotting were performed according to standard protocols. The DNA probe was the $1-\mathrm{kb}$ $M l u \mathrm{I} / E c o$ RI fragment of EACMCV DNA-A containing a partial segment of $\mathrm{AC} 1 \mathrm{ORF}$ and the intergenic region. Probe labeling, DNA hybridization, membrane washing, and detection were conducted using the North2South Chemiluminescent detection kits (Pierce Biotechnology, Inc. Rockford, IL, U.S.A.), as recommended by the manufacturer. Light signals produced were captured with a phosphoimager and were processed with the Quantity one imaging package (Bio-Rad, Hercules, CA, U.S.A.).

Table 6. Primers used to introduce mutations in East African cassava mosaic Cameroon virus

\begin{tabular}{|c|c|c|}
\hline Virus $^{\mathrm{a}}$ & Forward primer & Reverse primer \\
\hline $\mathrm{AC} 4^{\mathrm{M} 1 \mathrm{~T}}$ & GTCCTGATGTAGTTCTCTGCA & CAGAGAACTACATCAGGACGGGGTGCCTCATCTC \\
\hline $\mathrm{AC} 4^{\mathrm{G} 2 \mathrm{~A}}$ & GCCATCCTGATGTAGTTCTCTGC & GAGAACTACATCAGGATGGCGTGCCTCATCTCCA \\
\hline $\mathrm{AC} 4^{\mathrm{C} 3 \mathrm{~A}}$ & GCCCCCATCCTGATGTAGTTCTCTG & GAACTACATCAGGATGGGGGCCCTCATCTCCATG \\
\hline $\mathrm{AC} 4^{\mathrm{S} 6 \mathrm{~F}}$ & AAGATGAGGCACCCCATCCTGATG & ATGGGGTGCCTCATCTTCATGTTCTCATCCAATTC \\
\hline $\mathrm{AC} 4^{\mathrm{G} 2 \mathrm{AC} 3 \mathrm{~A}}$ & GCCGCCATCCTGATGTAGTTCTCTG & GAACTACATCAGGATGGCGGCCCTCATCTCCATG \\
\hline $\mathrm{AC} 4{ }^{\mathrm{M} 1 \mathrm{TS} 26 \mathrm{P} *}$ & GGATCGAAGAATCTGGGGTTGGT & GATTCTTCGATCCCATTTCCCCATCCCGAT \\
\hline AC4 $4^{\text {TAA9 }}$ & TAGAACATGGAGATGAGGCAC & GTGCCTCATCTCCATGTTCTAATCCAATTCGAAGG \\
\hline $\mathrm{AC} 4^{\mathrm{S} 15 \mathrm{~N}}$ & TTTGCCTTCGAATTGGATGAG & CTCCATGTTCTCATCCAATTCGAAGGCAAG \\
\hline $\mathrm{AC} 4^{\mathrm{S} 16 \mathrm{~F}}$ & AACTTGCCTTCGAATTGGATGAG & CCAATTCGAAGGCAAGTTCAATGTACCAACCCCA \\
\hline $\mathrm{AC} 4{ }^{\mathrm{T} 20 \mathrm{I}}$ & ATTGGTACATTGGAACTTGCC & CAAGTTCCAATGTACCAATCCCAGATTCTTCGATC \\
\hline $\mathrm{AC} 4^{\mathrm{S} 48 \mathrm{~L}}$ & AACATCGGACGATGATTTAGC & ATCATCGTCCGATGTTAAGGCTTACATTGAAAAG \\
\hline $\mathrm{AC} 4^{\mathrm{T} 51 \mathrm{I}}$ & ATAAGCCTTGACATCGGAC & CCGATGTCAAGGCTTATATTGAAAAGGGAGGGGAA \\
\hline $\mathrm{AC} 4^{\mathrm{S} 66 \mathrm{~L}}$ & AACTTGGAAAATTCCATCGTC & GACGATGGAATTTTCCAAGTTGATGCCAGAAGTGC \\
\hline $\mathrm{AC} 4^{\mathrm{T} 38 \mathrm{I}}$ & ATTCGGATGGAAATGTGTTG & ACACATTTCCATCCGAATATTCAGGGAGCTAAATC \\
\hline $\mathrm{AC}^{\mathrm{S} 76 \mathrm{~N}}$ & TTGGCCCTCCCCCCTG & CAGGGGGGAGGGCCAACATTTAGCTCAGGTATATG \\
\hline
\end{tabular}

\footnotetext{
${ }^{\mathrm{a}}$ An asterisk indicates primers were used to amplify DNA-A template $\mathrm{AC} 4{ }^{\mathrm{M} 1 \mathrm{~T}}$ to generate the $\mathrm{AC} 4{ }^{\mathrm{M} 1 \mathrm{TS} 26 \mathrm{P}}$ mutant.
} 


\section{DNA deep sequencing and data analysis.}

To determine the effect of AC4 mutations on genomic variability, we carried out a high-resolution deep sequencing of progeny viruses in $N$. benthamiana plants inoculated with AC4 mutant viruses. Changes occurring in the genome over the infection process were assessed by analyzing a series of libraries from two experiments. In the first experiment, samples were collected from inoculated leaves at $10 \mathrm{dpi}$ and from newly expanded leaves at 15 and $35 \mathrm{dpi}$. The leaves were pooled and total DNA was extracted as described above. Viral DNA was enriched by running total DNA on a $1 \%$ agarose gel from which bands between 1.5 to $2.0 \mathrm{~kb}$ were excised and DNA was isolated using Zymoclean gel DNA recovery kit (Zymo Research, Irvine, CA, U.S.A.). In the second experiment, libraries were prepared from total DNA collected from inoculated leaves at $5 \mathrm{dpi}$ and from systemic leaves at $15 \mathrm{dpi}$ and were then enriched using a rolling circle amplification (RCA) kit (Illustra TempliPhi, GE Healthcare Life Sciences, Piscataway, NJ, U.S.A.). Libraries from unamplified viral DNA (direct gel separation from total plant DNA) and RCA-amplified DNA were prepared using the Illumina TruSeq sample preparation kit. The viral DNA libraries were run on a HiSeq 2500 in $2 \times 151$ rapid run mode. Reads from the sequencing data were trimmed to remove poor-quality ends $(P<0.01$ or $q>$ 0.99 , $\max n=1$ ) and remnant adapter sequence (standard Illumina TruSeq adapters), using CLC Bio Genomics Workbench (v7.0.3) and Genomics Server (v6.0.4).

To align the reads to the EACMCV genome sequence, an index of the EACMCV genome sequence was built using the bowtie2-build command of the Bowtie2 2.3.2 package (Langmead and Salzberg 2012), followed by mapping of unique reads to the indexed genome using the bowtie2 alignment command. The output SAM files were converted to BAM files using the view command of SAMtools package (Li et al. 2009) and the BAM files were organized according to their positions in the genome, using the sort command of SAMtools. SNPs were then identified using the SAMtools mpileup function, which identifies alleles found at each position in the reference genome.

\section{ACKNOWLEDGMENTS}

We thank G. Sunter for helpful comments on the manuscript.

\section{LITERATURE CITED}

Ahmed, M. Z., Ren, S. X., Mandour, N. S., Maruthi, M. N., Naveed, M., and Qiu, B. L. 2010. Phylogenetic analysis of Bemisia tabaci (Hemiptera: Aleyrodidae) populations from cotton plants in Pakistan, China, and Egypt. J. Pest Sci. 83:135-141.

Batty, E. M., Wong, T. H. N., Trebes, A., Argoud, K., Attar, M., Buck, D., Ip, C. L., Golubchik, T., Cule, M., Bowden, R., Manganis, C., Klenerman, P., Barnes, E., Walker, A. S., Wyllie, D. H., Wilson, D. J., Dingle, K. E., Peto, T. E., Crook, D. W., and Piazza, P. 2013. A modified RNA-seq approach for whole genome sequencing of RNA viruses from faecal and blood samples. PLoS One 8:e66129.

Bi, H., Fan, W., and Zhang, P. 2017. C4 protein of Sweet potato leaf curl virus regulates brassinosteroid signaling pathway through interaction with AtBIN2 and affects male fertility in Arabidopsis. Front. Plant Sci. 8:1689.

Briddon, R. W., Patil, B. L., Bagewadi, B., Nawaz-ul-Rehman, M. S., and Fauquet, C. M. 2010. Distinct evolutionary histories of the DNA-A and DNA-B components of bipartite begomoviruses. BMC Evol. Biol. 10:97.

Bronstein, O., Kroh, A., and Haring, E. 2018. Mind the gap! The mitochondrial control region and its power as a phylogenetic marker in echinoids. BMC Evol. Biol. 18:80.

Carluccio, A. V., Prigigallo, M. I., Rosas-Diaz, T., Lozano-Duran, R., and Stavolone, L. 2018. S-acylation mediates Mungbean yellow mosaic virus AC4 localization to the plasma membrane and in turns gene silencing suppression. PLoS Pathog. 14:e1007207.

Cheleuitte-Nieves, C., Gulvik, C. A., McQuiston, J. R., Humrighouse, B. W., Bell, M. E., Villarma, A., Fischetti, V. A., Westblade, L. F., and Lipman, N. S. 2018. Genotypic differences between strains of the opportunistic pathogen Corynebacterium bovis isolated from humans, cows, and rodents. PLoS One 13:e0209231.

Chellappan, P., Vanitharani, R., and Fauquet, C. M. 2005. MicroRNAbinding viral protein interferes with Arabidopsis development. Proc. Natl. Acad. Sci. U.S.A. 102:10381-10386.

de Visser, J. A. G., Hermisson, J., Wagner, G. P., Ancel Meyers, L., BagheriChaichian, H., Blanchard, J. L., Chao, L., Cheverud, J. M., Elena, S. F., Fontana, W., Gibson, G., Hansen, T. F., Krakauer, D., Lewontin, R. C., Ofria, C., Rice, S. H., von Dassow, G., Wagner, A., and Whitlock, M. C. 2003. Perspective: Evolution and detection of genetic robustness. Evolution 57:1959-1972.

Deng, X. G., Zhu, T., Peng, X. J., Xi, D. H., Guo, H., Yin, Y., Zhang, D. W., and Lin, H. H. 2016. Role of brassinosteroid signaling in modulating Tobacco mosaic virus resistance in Nicotiana benthamiana. Sci. Rep. 6: 20579.

Dogra, S. C., Eini, O., Rezaian, M. A., and Randles, J. W. 2009. A novel shaggy-like kinase interacts with the Tomato leaf curl virus pathogenicity determinant C4 protein. Plant Mol. Biol. 71:25-38.

Doyle, J. J., and Doyle, J. L. 1987. A rapid DNA isolation procedure from small quantities of fresh leaf tissues. Phytochem. Bull. 19:11-15.

Draghi, J. A., Parsons, T. L., Wagner, G. P., and Plotkin, J. B. 2010. Mutational robustness can facilitate adaptation. Nature 463:353-355.

Earley, K. W., Haag, J. R., Pontes, O., Opper, K., Juehne, T., Song, K., and Pikaard, C. S. 2006. Gateway-compatible vectors for plant functional genomics and proteomics. Plant J. 45:616-629.

Elena, S. F. 2012. RNA virus genetic robustness: Possible causes and some consequences. Curr. Opin. Virol. 2:525-530.

Elmer, J. S., Brand, L., Sunter, G., Gardiner, W. E., Bisaro, D. M., and Rogers, S. G. 1988. Genetic analysis of the tomato golden mosaic virus. II. The product of the AL1 coding sequence is required for replication. Nucleic Acids Res. 16:7043-7060.

Etessami, P., Saunders, K., Watts, J., and Stanley, J. 1991. Mutational analysis of complementary-sense genes of African cassava mosaic virus DNA A. J. Gen. Virol. 72:1005-1012.

Fondong, V. N. 2013. Geminivirus protein structure and function. Mol. Plant Pathol. 14:635-649.

Fondong, V. N., and Chen, K. 2011. Genetic variability of East African cassava mosaic Cameroon virus under field and controlled environment conditions. Virology 413:275-282.

Fondong, V. N., Pita, J. S., Rey, M. E. C., de Kochko, A., Beachy, R. N., and Fauquet, C. M. 2000. Evidence of synergism between African cassava mosaic virus and a new double-recombinant geminivirus infecting cassava in Cameroon. J. Gen. Virol. 81:287-297.

Fondong, V. N., Reddy, R. V., Lu, C., Hankoua, B., Felton, C., Czymmek, K., and Achenjang, F. 2007. The consensus $N$-myristoylation motif of a geminivirus AC4 protein is required for membrane binding and pathogenicity. Mol. Plant-Microbe Interact 20:380-391.

García-Arenal, F., Fraile, A., and Malpica, J. M. 2001. Variability and genetic structure of plant virus populations. Annu. Rev. Phytopathol. 39: $157-186$.

Gutierrez, C. 1999. Geminivirus DNA replication. Cell. Mol. Life Sci. 56: 313-329.

Haley, A., Zhan, X., Richardson, K., Head, K., and Morris, B. 1992. Regulation of the activities of African cassava mosaic virus promoters by the AC1, AC2, and AC3 gene products. Virology 188:905-909.

Hipp, K., Grimm, C., Jeske, H., and Bottcher, B. 2017. Near-atomic resolution structure of a plant geminivirus determined by electron cryomicroscopy. Structure 25: P1303-1309.E3.

Hipp, K., Rau, P., Schäfer, B., Pfannstiel, J., and Jeske, H. 2016. Translation, modification and cellular distribution of two AC4 variants of African cassava mosaic virus in yeast and their pathogenic potential in plants. Virology 498:136-148.

Hong, Y., and Stanley, J. 1995. Regulation of African cassava mosaic virus complementary-sense gene expression by $\mathrm{N}$-terminal sequences of the replication-associated protein AC1. J. Gen. Virol. 76:2415-2422.

Hoogstraten, R. A., Hanson, S. F., and Maxwell, D. P. 1996. Mutational analysis of the putative nicking motif in the replication-associated protein (AC1) of bean golden mosaic geminivirus. Mol. Plant-Microbe Interact 9:594-599.

Jeske, H., Lütgemeier, M., and Preiss, W. 2001. DNA forms indicate rolling circle and recombination-dependent replication of Abutilon mosaic virus. EMBO J. 20:6158-6167.

Jiu, M., Zhou, X. P., Tong, L., Xu, J., Yang, X., Wan, F. H., and Liu, S. S. 2007. Vector-virus mutualism accelerates population increase of an invasive whitefly. PLoS One 2:e182.

Jupin, I., De Kouchkovsky, F., Jouanneau, F., and Gronenborn, B. 1994. Movement of tomato yellow leaf curl geminivirus (TYLCV): Involvement of the protein encoded by ORF C4. Virology 204:82-90. 
Lai, J., Chen, H., Teng, K., Zhao, Q., Zhang, Z., Li, Y., Liang, L., Xia, R., Wu, Y., Guo, H., and Xie, Q. 2009. RKP, a RING finger E3 ligase induced by BSCTV C4 protein, affects geminivirus infection by regulation of the plant cell cycle. Plant J. 57:905-917.

Langmead, B., and Salzberg, S. L. 2012. Fast gapped-read alignment with Bowtie 2. Nat. Methods 9:357-359.

Latham, J. R., Saunders, K., Pinner, M. S., and Stanley, J. 1997. Induction of plant cell division by beet curly top virus gene C4. Plant J. 11: 1273-1283.

Lauring, A. S., Frydman, J., and Andino, R. 2013. The role of mutational robustness in RNA virus evolution. Nat. Rev. Microbiol. 11:327-336.

Legg, J. P., and Fauquet, C. M. 2004. Cassava mosaic geminiviruses in Africa. Plant Mol. Biol. 56:585-599.

Li, H., Handsaker, B., Wysoker, A., Fennell, T., Ruan, J., Homer, N., Marth, G., Abecasis, G., Durbin, R., and 1000 Genome Project Data Processing Subgroup. 2009. The sequence alignment/map format and SAMtools. Bioinformatics 25:2078-2079.

Li, H., and Roossinck, M. J. 2004. Genetic bottlenecks reduce population variation in an experimental RNA virus population. J. Virol. 78:10582-10587.

Li, H., Zeng, R., Chen, Z., Liu, X., Cao, Z., Xie, Q., Yang, C., and Lai, J. 2018. S-acylation of a geminivirus C4 protein is essential for regulating the CLAVATA pathway in symptom determination. J. Exp. Bot. 69: 4459-4468.

Masel, J., and Trotter, M. V. 2010. Robustness and evolvability. Trends Genet. 26:406-414.

Mei, Y., Wang, Y., Hu, T., Yang, X., Lozano-Duran, R., Sunter, G., and Zhou, X. 2018a. Nucleocytoplasmic shuttling of geminivirus C4 protein Mediated by phosphorylation and myristoylation is critical for viral pathogenicity. Mol. Plant 11:1466-1481.

Mei, Y., Yang, X., Huang, C., Zhang, X., and Zhou, X. 2018b. Tomato leaf curl Yunnan virus-encoded $\mathrm{C} 4$ induces cell division through enhancing stability of Cyclin D 1.1 via impairing NbSK $\eta$-mediated phosphorylation in Nicotiana benthamiana. PLoS Pathog. 14:e1006789.

Melgarejo, T. A., Kon, T., Rojas, M. R., Paz-Carrasco, L., Zerbini, F. M., and Gilbertson, R. L. 2013. Characterization of a new world monopartite begomovirus causing leaf curl disease of tomato in Ecuador and Peru reveals a new direction in geminivirus evolution. J. Virol. 87:5397-5413.

Mills-Lujan, K., Andrews, D. L., Chou, C.-W., and Deom, C. M. 2015. The roles of phosphorylation and SHAGGY-like protein kinases in geminivirus C4 protein induced hyperplasia. PloS One 10:e0122356.

Mills-Lujan, K., and Deom, C. M. 2010. Geminivirus C4 protein alters Arabidopsis development. Protoplasma 239:95-110.

Patel, V. P., Rojas, M. R., Paplomatas, E. J., and Gilbertson, R. L. 1993. Cloning biologically active geminivirus DNA using PCR and overlapping primers. Nucleic Acids Res. 21:1325-1326.

Piroux, N., Saunders, K., Page, A., and Stanley, J. 2007. Geminivirus pathogenicity protein C4 interacts with Arabidopsis thaliana shaggyrelated protein kinase AtSKeta, a component of the brassinosteroid signalling pathway. Virology 362:428-440.

Pita, J. S., Fondong, V. N., Sangaré, A., Otim-Nape, G. W., Ogwal, S., and Fauquet, C. M. 2001. Recombination, pseudorecombination and synergism of geminiviruses are determinant keys to the epidemic of severe cassava mosaic disease in Uganda. J. Gen. Virol. 82:655-665.

Pooma, W., and Petty, I. T. 1996. Tomato golden mosaic virus open reading frame AL4 is genetically distinct from its C4 analogue in monopartite geminiviruses. J. Gen. Virol. 77:1947-1951.

Power, A. G. 2000. Insect transmission of plant viruses: A constraint on virus variability. Curr. Opin. Plant Biol. 3:336-340.
Ramesh, S. V., Sahu, P. P., Prasad, M., Praveen, S., and Pappu, H. R. 2017. Geminiviruses and plant hosts: A closer examination of the molecular arms race. Viruses 9:256.

Rigden, J. E., Krake, L. R., Rezaian, M. A., and Dry, I. B. 1994. ORF C4 of tomato leaf curl geminivirus is a determinant of symptom severity. Virology 204:847-850.

Rojas, M. R., and Gilbertson, R. L. 2008. Emerging plant viruses: a diversity of mechanisms and opportunities. Pages 27-51 in: Plant virus evolution. M. J. Roossinck, ed. Springer-Verlag, Berlin, Germany.

Roossinck, M. J., Kaplan, I., and Palukaitis, P. 1997. Support of a cucumber mosaic virus satellite RNA maps to a single amino acid proximal to the helicase domain of the helper virus. J. Virol. 71:608-612.

Saunders, K., Lucy, A., and Stanley, J. 1991. DNA forms of the geminivirus African cassava mosaic virus consistent with a rolling circle mechanism of replication. Nucleic Acids Res. 19:2325-2330.

Seal, S. E., vandenBosch, F., and Jeger, M. J. 2006. Factors influencing begomovirus evolution and their increasing global significance: Implications for sustainable control. Crit. Rev. Plant Sci. 25:23-46.

Sobel Leonard, A., McClain, M. T., Smith, G. J., Wentworth, D. E., Halpin, R. A., Lin, X., Ransier, A., Stockwell, T. B., Das, S. R., Gilbert, A. S., Lambkin-Williams, R., Ginsburg, G. S., Woods, C. W., and Koelle, K. 2016. Deep Sequencing of influenza A virus from a human challenge study reveals a selective bottleneck and only limited intrahost genetic diversification. J. Virol. 90:11247-11258.

Stanley, J., and Latham, J. R. 1992. A symptom variant of beet curly top geminivirus produced by mutation of open reading frame $\mathrm{C} 4$. Virology 190:506-509.

Stanley, J., Markham, P. G., Callis, R. J., and Pinner, M. S. 1986. The nucleotide sequence of an infectious clone of the geminivirus beet curly top virus. EMBO J. 5:1761-1767.

Stenger, D. C., Revington, G. N., Stevenson, M. C., and Bisaro, D. M. 1991. Replicational release of geminivirus genomes from tandemly repeated copies: Evidence for rolling-circle replication of a plant viral DNA. Proc. Natl. Acad. Sci. U.S.A. 88:8029-8033.

Sung, Y. K., and Coutts, R. H. 1995. Mutational analysis of potato yellow mosaic geminivirus. J. Gen. Virol. 76:1773-1780.

Teng, K., Chen, H., Lai, J., Zhang, Z., Fang, Y., Xia, R., Zhou, X., Guo, H., and Xie, Q. 2010. Involvement of C4 protein of beet severe curly top virus (family Geminiviridae) in virus movement. PLoS One 5:e11280.

Tweedy, J. G., Prusty, B. K., and Gompels, U. A. 2017. Use of whole genome deep sequencing to define emerging minority variants in virus envelope genes in herpesvirus treated with novel antimicrobial K21. Antiviral Res. 146:201-204.

Vanitharani, R., Chellappan, P., Pita, J. S., and Fauquet, C. M. 2004. Differential roles of AC2 and AC4 of cassava geminiviruses in mediating synergism and suppression of posttranscriptional gene silencing. J. Virol. 78:9487-9498.

Watson, C. M., Crinnion, L. A., Gurgel-Gianetti, J., Harrison, S. M., Daly, C., Antanavicuite, A., Lascelles, C., Markham, A. F., Pena, S. D. J., Bonthron, D. T., and Carr, I. M. 2015. Rapid detection of rare deleterious variants by next generation sequencing with optional microarray SNP genotype data. Hum. Mutat. 36:823-830.

Willemsen, A., Zwart, M. P., Higueras, P., Sardanyés, J., and Elena, S. F. 2016. Predicting the stability of homologous gene duplications in a plant RNA virus. Genome Biol. Evol. 8:3065-3082.

Zhang, D. W., Deng, X. G., Fu, F. Q., and Lin, H. H. 2015. Induction of plant virus defense response by brassinosteroids and brassinosteroid signaling in Arabidopsis thaliana. Planta 241:875-885. 